\title{
With víkingr into the Identity Trap: When Historiographical Actors get a Life of their Own
}

\author{
Kerstin P. Hofmann*
}

As the field of genetic history has grown, academic interest in migration, peoples and ethnic identities has also grown apace. The people of the British Isles have been a focus of research in this area. Specifically, researchers have been fishing for Vikings in the gene pool. My paper begins, therefore, with some brief remarks on the etymology of the term »Viking «, its historical usage and the reception of Vikings in modern times. I address practices of naming as well as the role of romanticization and mythologization as constituents of the popular image of »the Vikings «. The discussion makes it apparent that the term »Viking « has a wide variety of associations and that behind the shared designation, which functions as a kind of semantic shorthand, lie many relationships that have yet to be studied. For that reason, in a second step, this paper outlines what are, in some cases, the greatly diverging conceptualizations of time, space, mobility and identity on which archaeological and genetic interpretations are based. I discuss in particular the problem posed by the essentialization of archaeological subjects as well as the "naturalization « of protagonists of historiographical narratives and their equation with historical actors. Finally, I address the dangers associated with identity politics, which go on both outside the academic discourse and within academia itself. Our duty now is to steer clear of mere battles over the prerogatives of interpretation. Instead, we must cultivate academic and political reflexivity, as well as mutual acceptance. Only by doing so will we be able to explore questions - and they are important questions - concerning the constitution and historicization of identities, interactions among migrations, mobility and identity, and about the relationships between biological and social reproduction.

Keywords: Vikings; historiography; Britain; genetic history; archaeology.

Is it possible to »fish for Vikings ${ }^{1}$ in the gene pool«? Is there such a thing as »Viking DNA«? We often see phrases like these, not framed as questions as they are here, but as headings in the context of projects and publications investigating human genetic diversity, and the

* Correspondence details: Kerstin P. Hofmann, Römisch-Germanische Kommission des Deutschen Archäologischen Instituts, Palmengartenstraße 10-12, 60325 Frankfurt am Main. Email: kerstin.hofmann@dainst.de.

1 In some historical studies, putting the word /Viking in upper case gives it in English the status of a nationality. More and more scholars are now abandoning that practice and leaving it in lower case. This might signal a deliberate distancing form the loaded usage of the past, but there is also an argument that it gives the word a clearer frame of reference as a descriptor based on something to do with activity. In the archaeological and genetic studies quoted here this distinction is not made. Furthermore, in my mother tongue, German, this differentiation cannot be made. For these reasons, I have decided not to distinguish between upper and lower case Vikings in this paper. 
history of the population of the British Isles in particular. ${ }^{2}$ My answer to all such questions is no, but not out of any wish on my part to reject the results of genetic analysis or because I do not find the relevant studies extremely interesting and fruitful. Rather, we need to ask different questions if we are to have a constructive collaboration between archaeology, history and genetics. And besides, it is not terminology alone which is at issue. ${ }^{3}$ To avoid raising false expectations or even fears, it is essential to communicate clearly that DNA, though it can be an identity resource for contemporary people, was irrelevant for the constitution of identities in the past. Nonetheless, the emerging discipline of genetic history does pose an important challenge both for our current Western academic conceptions of identities, human communities and persons, and for our historiographical narratives. Moreover, genes do constitute an important historical source, one whose value we are only now, slowly, learning to assess correctly.

When grappling with issues of identity, a subject that always seems fraught with danger these days, more and more people are turning to geneticists for an answer to the question of who they are. This is not surprising: genetics is seen as an exact natural science, and one of its applications is the identification of individuals in law enforcement contexts. Outside of the academic sphere, this situation has resulted in the establishment of genetic ancestry testing companies that serve private individuals, and the publication of a steadily growing number of popular science books and newspaper articles on questions of who is descended from which peoples/cultures. The thought processes reflected in the answers these publications provide tend to be outdated, and though occasionally one does see evidence of new thought processes, even these are relatively simplistic. ${ }^{4}$ The situation has had an impact within the academic sphere as well: many researchers today either try to avoid the racially and völkisch charged tendencies and interpretations that often quickly infuse discussions of these topics these days, or they deliberately attempt to combat them. Some do so while continuing to use genetics, while in the humanities some scholars completely reject the use of those particular methods to answer questions of identity. ${ }^{5}$ Just what is it though that lies behind the - at times extremely controversial - field of genetic history? In the following, I will attempt to shed light on certain aspects and basic premises of research in genetic history, and point up future challenges for the field and its integration into society, taking as my example the current focus on "Vikings«, and the genetic survey of Wirral and West Lancashire in particular. ${ }^{6}$

2 Phrases borrowed from the title of a lecture by Mark A. Jobling, "Fishing in the Gene Pool for Vikings «, unpublished lecture given at the conference "Genetic History: A Challenge to Historical and Archaeological Studies", Humboldt-Universität zu Berlin, 2 October 2015: www.genetic-history.com/wissenschaft/programm.htm (retrieved on 21 April 2016) and Harding et al., Viking DNA.

3 This paper is written from the point of view of a German archaeologist. The remarks are addressed mainly to archaeologists, but much of the discussion applies to all students of the Viking age, including historians, literary scholars and linguists, as well as scientists such as physical anthropologists and geneticists. Furthermore, I hope that some of the general points might also be of interest for all kinds of scholars to become involved with genetic history.

4 Sykes, Blood of the Isles; Oppenheimer, Origins of the British; cf. Wiwjorra, Ethnische Anthropologie.

5 E.g., Bamshad et al., Deconstructing the Relationship between Genetics and Race; Pluciennik, Genetics, Archaeology and the Wider World, 14.

6 Bowden et al., Excavating Past Population Structures; Harding et al., Viking DNA; Harding et al., In Search of the Vikings; Griffiths et al., Looking for Vikings in North-West England; see also Goodacre et al., Genetic Evidence for a Family-based Scandinavien Settlement; McEvoy et al., Scale and Nature of Viking Settlement. 
My paper starts with the question of what lies behind the word "Viking". In my analysis, I look at practices of naming as well as semantic simplifications, and at romanticization and mythologization as constituents of the popular image of "the Vikings «. I also examine the divergent concepts of time, space, mobility and identity on which archaeological and genetic interpretations are based. I then turn to the dangers of identity politics, which occur both outside of the academic discourse and within academia itself. In my conclusion, I argue that both more reflexivity and mutual acceptance are needed if we are to establish good ways of collaborating with each other.

Vikings: what's in the name?

"Names go with identities and identities go with names. " ${ }^{7}$

Recently, Turi King and Mark Jobling posed the elegant and succinct question, "What's in a name? « for the field of genetics. ${ }^{8}$ Admittedly, their focus at the time was on heritable surnames, not on the meaning of the term $»$ Vikings $« .{ }^{9}$ King and Jobling wanted to increase the probability of acquiring new information about past population movements from modern DNA samples through the selection of sample subjects whose surnames have long been present in the region under study. In general, however, publications relating to genetic ancestry usually fail to provide in-depth treatment of the potential ancestral peoples involved. It is also rare to find researchers systematically tackling questions of eponymy. ${ }^{10}$ Far more common is the preference to rely on "proper names already filled $",{ }^{11}$ i.e., to use proper nouns about which readers have pre-existing knowledge because the terms are already familiar from other contexts. ${ }^{12}$ This was long the standard practice in the fields of prehistoric and early historic archeology - and one to some extent still standard today - when referring to the ethne mentioned in written sources, for instance. ${ }^{13}$ Thus, scholars intentionally use the "significance of names ${ }^{14}$ as a way of integrating their findings within familiar narratives.

7 Brendler, Identity of Name(s), 29.

8 King and Jobling, What's in a Name? This is the rhetorical question about the meaning of proper names, frequently quoted in studies on names, that Shakespeare has Juliet ask as she laments the fact that her beloved Romeo bears the hated name of Montague; see, for example, Zabeeh, What is in a Name?; Carroll, What's in a Name?; Haubrichs, Einleitung.

9 For further literature on the relation of surnames and genes see Jobling, In the Name of the Father; King and Jobling, Founders, Drift, and Infidelity; Redmonds et al., Surnames, DNA, and Family History; Sykes and Irven, Surnames and the Y Chromosome; Winney et al., People of the British Isles.

10 Though this has not been not unheard of recently, from the history of science and classical studies perspectives: Cancik-Kirschbaum and Wiedemann, Historische Variablen und narrative Identität.

11 De Certeau, Writing of History, 95.

12 One exception here is Bryan Sykes, Professor of Human Genetics (now emeritus) at the University of Oxford; however Sykes has also since come under criticism among geneticists for other premature, since disproven assertions. Sykes published a book presenting research on human mitochondrial haplogroups for a general audience in which he wrote the stories of hypothetical prehistoric "clan mothers", not only assigning them specific women's names, but also including a brief description of their lives and environments (Sykes, Seven Daughters of Eve).

13 Cf. Brather, Ethnische Interpretationen; Fehr, Germanen und Romanen im Merowingerreich.

14 According to the Swiss philologist Stefan Sonderegger, the term "significance of a name (Namensbedeutsamkeit) should be understood as the sum of all of the associations, ideas and emotions associated with that name. The significance of a name at any given time, Sonderegger says, arises through the interplay among (i) the name itself in the expressivity of its sound-gestalt and written form; (ii) the category of people who bear the name, as a reference subject/object and (iii) the use of the name by speakers or the speech community (Sonderegger, Bedeutsamkeit der Namen). 
In the face of criticism, however, those same scholars often take up a nominalistic position vis-à-vis these names: i.e., the designation is presented as a terminus technicus. The names of persons or groups serve purposes of identification and individuation. Through names, we can identify that which is meant at a single stroke, as it were,${ }^{15}$ because the moment we give someone or something a proper name, we have also - usually implicitly - defined a rule for its usage. By doing so we have also established an identity criterion for the person or thing named, one that is intended to make it possible to individuate it according to its type. ${ }^{16}$ In addition, the names of groups are intended to denote, as far as possible, persons or things that are the same, or similar; however, this also amounts to a delimitation excluding other persons or things. In addition, group names are also used to establish affiliations. They can be used to express positions and relationships within a single matrix of meaning, albeit one in constant flux. ${ }^{17}$ It is essential to bear in mind in this regard, however, that names also serve as containers for meaning, containers to which characteristics and actions are assigned, though such assignments can also be revoked at times.

How do and did people understand the word "Viking «? In the effort to find out, it is helpful to differentiate among the analyses of its etymology, historical usage and current usage. ${ }^{18}$ Two Old West Norse words, víkingr and víking, commonly serve as references for our contemporary term »Viking". Despite a century of intensive study, though, no consensus about the origin of those words has emerged..$^{19}$ Only on the following points is there broad agreement: The two words probably both came from the North-West Germanic dialect, and both appear to have been very closely linked with ships and seafaring. While there is no surviving evidence in Scandinavia of either the masculine noun víkingr (for a person) or of the feminine noun víking (for an activity) in Old West Norse that dates from before the second half of the tenth century, counterparts for both words in Old English are found in glossaries dating as far back as the seventh/eighth century. There is also evidence of the words in poems written in Old English, though their chronological positioning is the subject of dispute. The general meaning of the words as common nouns denoting pirates and piracy appears to predate the geographical restriction to the Scandinavian region and the use of the word as part of a personal name. The earliest evidence of the above-mentioned two specifications víkingr and viking is found in Ælfric's Grammar and on rune stones from the tenth and eleventh centuries. ${ }^{20}$

This brings us to the historical usage of the words, since the Viking period is normally dated as lasting from the late eight until the mid-eleventh century on the basis of events recorded in writing. The only clue in the continental European sources, is found in the writings of the Adam of Bremen, who mentions that northern pirates were called wichingos by others. ${ }^{21}$ Otherwise, the Frankish chronicles always speak in terms of normanni or nort-

pontificum $I V, 6$, ed. Trillmich and Buchner 440, 23-26).

Descombes, Rätsel der Identität, 68-69.

Gruner, Gestatten mein Name ist Hase.

Jesch, Viking Diaspora, 4-8.

Andersson, Wikinger.

Krüger, »Wikinger« im Mittelalter, 2-3, 42-47.
"Durch sie identifzieren wir gleichsam mit einem Schlage das Gemeinte« (Debus, Namen in literarischen Werken, 19). 
manni. ${ }^{22}$ By contrast, the Old English sources refer to wicinge, hæðen, Dene and Norðmenn. ${ }^{23}$ On the whole, the non-Norse sources present a quite stereotypical picture of the Vikings, one that adheres largely to the barbarian cliché of the Ancient World. The Vikings are firmly established in the role of the heathen pirate, their raids seen as a punishment for past sins; hence they function as a representation of "the Other " for Christian civilization. ${ }^{24}$ One finds only scattered mention of Viking voyages/voyagers in the contemporary runic writings from Denmark, Sweden and Gotland. ${ }^{25}$ In those contexts, these ventures are described as bringing glory, as they are later, in the early phase of the sagas. ${ }^{26}$ It is important to note, then, that the temporary activity of piracy and the category of origin (though the latter to only a limited degree) - and not the category of ethnicity as a self-defined collective identity - applied as the defining criteria for the contemporary term denoting Viking. However it must be said that this reconstruction of the concept "Vikings « is based on only a small number of biased sources, which include terminological conventions more than anything else.

Not until the narrative vernacular sources of the High Middle Ages do we find a more comprehensive, but also highly mythologized, picture of the Viking voyages. ${ }^{27}$ These texts, along with the works of sixteenth century Gothicism, constitute the reference sources for the "Vikings «, which figure prominently in public discourse and historiography in the eighteenth and nineteenth centuries. Here the "Vikings « function as an antithesis to the Occidental tradition, one that is assessed positively in multiple respects and is linked with a topos of freedom. Only Franco-centric historiography takes a considerably more negative attitude vis-à-vis the "Vikings". Thus "Viking", once a narrow term, had long since become a broader, völkisch term. In this newer meaning it even served as source material for fascist models of society. ${ }^{28}$

References to the grievously misused Vikings become more rare in the aftermath of World War II. In Germany, in particular, they did not return to prominence again until the 1960 s/70s, when they begin to figure as the antiheroes of children's books, animated films and comic books. ${ }^{29}$ Today we encounter them both as highly versatile advertising characters and as reference figures for religious and political groupings. ${ }^{30}$ The word "Viking " also serves

23 It was long assumed that Dene and Norðmenn were used to distinguish separate ethnic groups - in fact, they were often equated with the national labels "Dane« and "Norwegian«, but today scholars are relatively certain that Dene and Norðmenn were more or less interchangeable in English sources from the Viking Age (Downham, >Hiberno-Norwegians` and >Anglo-Danes`).

24 Böldl, Wikinger, 698-700.

25 Krüger, »Wikinger« im Mittelalter, 42-47.

26 Cf. Jesch, Ships and Men in the Late Viking Age.

27 In addition to the skaldic poetry - here it is argued that much of the surviving verses, although preserved in later narratives, is early, perhaps even contemporary - it is particular true for the sagas and the Gesta Danorum of Saxo Grammaticus.

28 Böldl, Wikinger, 705-707; cf. Müller-Wille, Political Misuse of Skandinavian History; Wawn, Vikings and the Victorians.

29 Particularly popular, aside from »Vicke Viking«, a series of children's books by Swedish author Runer Jonsson, which served as the inspiration for several other works including two animated television series and two films, was »Hägar the Horrible«, an American comic strip created by Dik Browne, and which first appeared in 1973 . The caricatures were widely disseminated, primarily through syndication in numerous newspapers.

30 Hein, Mythos und Legende. 
as a possible designation of origin, and, lately, Vikings have begun to appear in the role of heroic protagonists again, e.g., in the much-watched Irish-Canadian historical drama television series Vikings. ${ }^{31}$

Meanwhile, another concept of Viking has been evolving in the field of archaeology. This concept has contributed to the production and reception of the many images of Vikings, but done so very unevenly. ${ }^{32}$ Archaeologists associate what they view as a characteristic material culture - which includes certain fibula and sword types, steatite, ship and building forms, stone monuments, but also a series of art styles and burial forms - with Scandinavia or the presence of Scandinavians. ${ }^{33}$ This bundle of characteristics is supplemented, primarily by historians, with data and descriptions relating to historical events, ${ }^{34}$ as well as with the names of persons and places supplied by historical linguists, ${ }^{35}$ and, lately, with haplotypes from geneticists. ${ }^{36}$ Despite criticism of the ethnic interpretation and the overly close association of things or actions with the bearers of a geographically referenced culture, the classification remains in use to a great extent, though increasingly with the qualification that it constitutes an analytical category, ideal type or narrative figure. And although some researchers deliberately focus on aspects of diversity in small-scale investigations, rarely is the superordinate entities - »the Vikings « in our example - challenged at a fundamental level.

Yet archaeologists are co-producers ${ }^{37}$ of the images of Vikings and as such they cannot be careful enough..$^{38}$ One need only look at the cover of the album »This Time the World " (which was placed on Germany's official list of media harmful to young persons) by British skinhead band No Remorse to see why: it depicts what for neo-Nazis is the perfect ancestral line-up, a skinhead, a Nazi-soldier and a Viking warrior. ${ }^{39}$

31 www.history.com/shows/vikings; retrieved on 7 June 2016.

32 The horned helmets so frequently associated with Vikings reveal just how immune the popular image of Vikings can be to the influence of archaeological knowledge. This invention of Romanticism goes back to artists such as Gustav Malmström, who illustrated an edition of Frithiof's Saga, and Carl Emil Doepler, who created horned helmets for the first Bayreuth Festival production of Wagner's opera "Der Ring des Nibelungen« in 1876. However, there is no archaeological evidence that Scandinavians in the Viking Age wore them (Richard, Vikings, 120; cf. Frank, Invention of Viking Horned Helmet).

33 See e.g., Brather, Lindisfarne; Brink and Price, Viking World.

34 E.g., Sawyer, Kings and Vikings; Smyth, Scandinavian York and Dublin.

35 E.g., Fellows-Jensen, Scandinavian Personal Names; Fellows-Jensen, Vikings in the British Isles.

36 Bowden et al., Excavating Past Population Structures; Harding et al., Viking DNA, 62-68, 102-109.

37 Jasanoff, Idiom of Co-Production; Cf. M'charek et al., Topologies of Race; Schramm, Neue Technologien; Schreiber, Vergangenheit als personaler Wissensraum.

38 This applies in particular to major exhibitions such as the 22nd Council of Europe exhibition »From Viking to Crusader - Scandinavia and Europe 800-1200« in Paris, Berlin and Copenhagen, 1992-1993, and the international exhibition "Vikings: Life and Legend « in Copenhagen, London and Berlin, 2013-2014 (Roesdahl and Wilson, From Viking to Crusader; Williams et al., Vikings). Particularly vigilant regarding the various political entanglements is the current exhibition in Rosenheim »Wikinger!« (Helmbrecht, Wikinger!). A systematic comparative study of archaeological Viking exhibitions and their reception is still to be made.

39 The album was released in 1988 by the French white power rock record label Rebelles Européens. No Remorse was one of the most influential and radical right-wing rock bands. The band was part of the Blood \& Honour network (Helmbrecht, Wikinger und die politisch Rechte, 267; Raabe and Schlegelmilch, Rezente extreme Rechte, 174-175; cf. Menhorn, Skinheads, 115-116). 
Applied to "Vikings", the question "What's in a name? « can ultimately only be studied contextually, e.g., through what are known as topological analyses. ${ }^{40}$ Nonetheless, my survey points up concepts that have repeatedly been of relevance for the definition of the term ॥Vikings «: time, space, mobility and identity. In the following, I provide a brief outline describing how each of these four concepts is used in the context of the analysis of Vikings in archaeology and population genetics. It should also have become clear from my survey that while the shared name increases the potential for tie-ins, it also works as a smokescreen, obscuring the interconnections that may have existed in some form among individual characteristics/features, persons and ways of living, and thus preventing their examination or scrutiny. What is actually needed is systematic differentiation.

\section{Central Concepts}

Time

In archaeology, past and present are seen as two separate, but relationally conceived worlds. Their relationship to one another is defined through continuity and discontinuity and through distance and proximity, and is renegotiated over and over again through othering, historical traditions and nostrification ${ }^{41}$ (Fig. 1).

The notion of an irretrievable past results in the creation of insurmountable distance, and thus, discontinuity. There is a reason that archaeologists and historians researching far-off periods say that they study dead cultures. ${ }^{42}$ On the other hand, though, they assume that

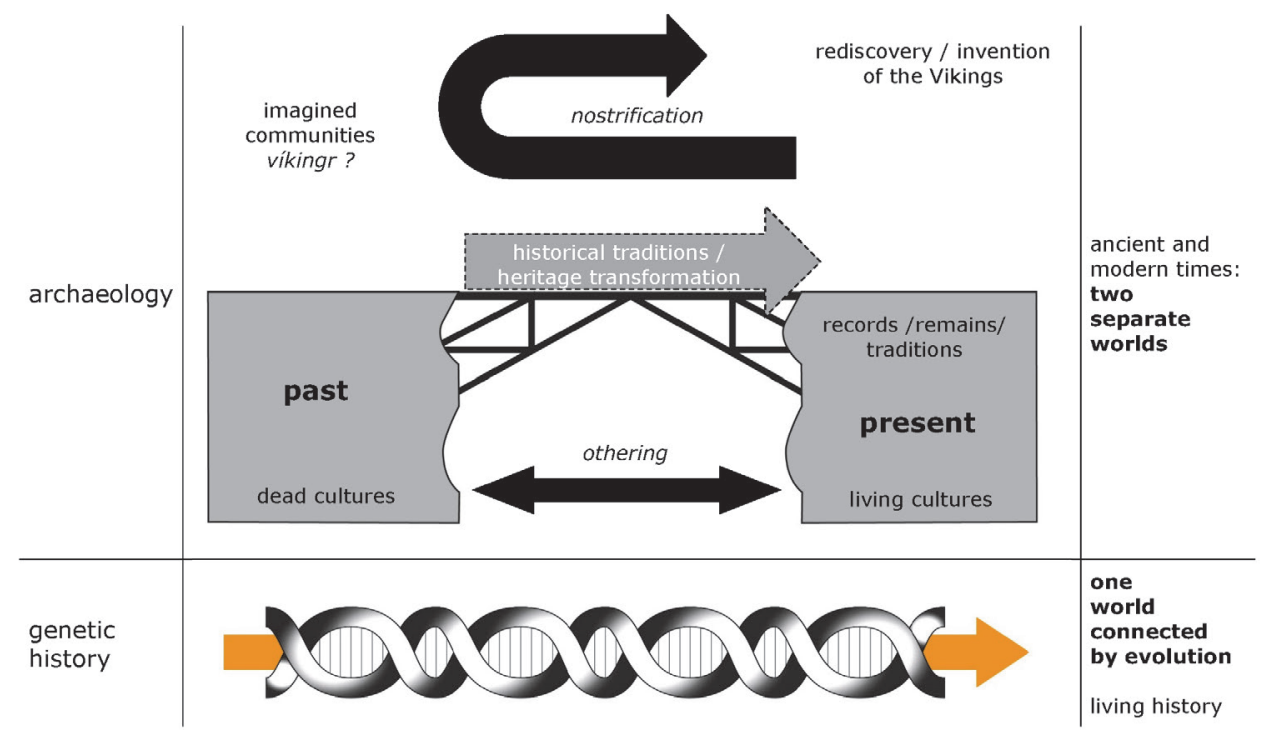

Fig. 1.: Time concepts in archaeology and genetic history: a comparison (Layout: Kerstin P. Hofmann and Blandina C. Stöhr)

40 M'charek et al., Topologies of Race; Serres, Aufklärungen; Schramm, Neue Technologien - alte Kategorien.

41 Cultural appropriation of the other, sometimes even accompanied by claims that the formerly other has always been part of one own's culture.

42 Eggert, Prähistorische Archäologie, 112; Eggers, Einführung in die Vorgeschichte, 258-262; cf. Lucas, Understanding the Archaeological Record, 54-55, 59, 100. 
remnants or traces left behind in their transformed residuality project out of the past and into the present, and they usually even grant our historical sources a power of veto on false or unreliable representation of the past. ${ }^{43}$ They further assume that past actions and structures have effects, some of which carry over into the present. The historical potency/efficacy and degree of path dependence ${ }^{44}$ varies considerably, however. In many cases these are gauged as being fairly minor, particularly for cultures and periods that do not stand in direct relation to one another. Moreover they can be influenced by the actors of the respective present(s). For instance, it is possible to surmount the divide between ancient and modern times with the help of constructions of meaning, e.g., genealogies ${ }^{45}$ or invented traditions, ${ }^{46}$ but also through development thinking. ${ }^{47}$ Continuities and coherences postulated in this manner relink the past and the present, lending archaeology a particular appeal, even in the eyes of the public, and particularly at times of social upheaval. In the end, this is the only way to explain the significant role that archaeology has played for the construction of identities and in the current history and heritage boom. ${ }^{48}$ Identity narratives established in this way, however, are predominantly part of intentional history ${ }^{49}$ or also applied history..$^{50}$ Archaeological analysis, though, requires us to consider archaeological cultures as alien..$^{51}$ We use distancing as a means to try to prevent the unthinking transfer of unexamined premises of the present day onto prehistory and early history. This issue also came up above, in my consideration of the term Viking.

In the field of genetics, and also that of genetic history, scholars assume the existence of a world that links past and present through evolution. In this context the meaning of DNA appears to be self-referential: there is a trajectory that leads directly from the past to the present (Fig. 1). In his 2006 bestseller Blood of the Isles, Bryan Sykes, Professor of Human Genetics (now emeritus) at the University of Oxford and founder of the genealogical DNA testing firm Oxford Ancestors expressed this as follows: "It is a living history, told by the real

43 Hofmann, Dinge als historische Quelle in Revision, 286; cf. Koselleck, Standortgebundenheit und Zeitlichkeit; Jordan, Vetorecht der Quelle.

44 Concept developed by economic historian Paul A. David and the economist and mathematician W. Brian Arthur, that is now used in a less deterministic sense in other fields, such as the social sciences and history of science, though not without extensive criticism. Path dependencies refer to critical junctures of the past, which substantially define or at least restrict the trajectory of future development, because once paths have been taken it becomes easier to continue along them due to the regular antecedent conditions associated with them, such as institutional settings, high fixed costs, feedback processes, reduced coordination costs, etc.; see Beyer, Pfadabhängigkeit; Werle, Pfadabhängigkeit.

45 Renger and Toral-Niehoff, Genealogie und Migrationsmythen.

46 Hobsbawm, Introduction; cf. Boschung et al., Reinventing »The Invention of Tradition«?

47 For a critical view: Cesana, Geschichte als Entwicklung.

48 Cf. Lowenthal, Heritage Crusade; Tschofen, Antreten, ablehnen, verwalten?

49 Term coined by the historian of antiquity Hans-Joachim Gehrke in 1994. "Intentional history [...] is the projection in time of the elements of subjective, self-conscious self categorization which construct the identity of a group as group «; Foxhall and Luraghi, Introduction, 9; cf. Gehrke, Mythos, Geschichte, Politik, 247; Foxhall et al., Intentional History; Gehrke, Hans-Joachim, Geschichte als Element antiker Kultur.

50 Applied history is history that is applied to real-world issues. Sometimes the term was used synonymously and interchangeably with public history, but applied history better highlights that this kind of historiography especially takes account of the intellectual and practical needs of society and often goes hand in hand with commercialization; cf. Hardtwig and Schug, History Sells; Nießer and Tomann, Angewandte Geschichte; Sommer, Angewandte Geschichte auf genetischer Grundlage; Tomann et al., Diskussion Angewandte Geschichte.

51 Röder, Jäger sind anders; Veit, Archäologe und das Fremde. 
survivors of the times: the DNA that still lives within our bodies. This really is the history of the people, by the people. ${ }^{52}$ Certainly, this assertion has also served the marketing of Sykes' business. (Concerns about situations like this, incidentally, were one of the motivations behind the development of honour codes in the field of archaeology - regrettably only very late in the day - which include a provision barring archaeologists from simultaneously being collectors and/or antique dealers). ${ }^{53}$ Nonetheless, more recent studies on Viking DNA have also emphasized the direct link to history, and also their ideologically less-problematic approach to history. ${ }^{54}$ Despite the advances in aDNA analysis, these studies usually start from modern populations whose data are also better suited for other forms of use, such as in medical or forensic investigations. Human biologists' interest in studying the genetic legacy of the Vikings on the British Isles can also be traced to the desire to understand what it means to be British..$^{55}$ And the new "Impact of Diasporas..." "research project is interested above all in diasporas' impact "...on the Making of Britain.$^{56}$ These issues are embedded in a larger research environment that, since early in this millennium, has increasingly been shifting away from earlier tendencies to emphasize biological equality and towards the study and mapping of the 0.1 percent difference among people..$^{57}$ In this context, the intent is not to learn through the past or history through contrasted otherness and diversity - an approach increasingly prevalent in historiography and archaeology - but instead to do so through the understanding of origin, descent and difference, and recently, to a greater extent also, through an understanding of the admixtures of populations.

Other differences in the treatment of time can also be identified, however. For instance, the "molecular clock ${ }^{58}$ still ticks considerably more slowly than its archaeological counterpart. Nonetheless, long-term developments are linked with data and persons associated with historic events mentioned in written sources - as was the standard practice in archaeology for a long time, and, despite criticism, ${ }^{59}$ is still, in some respects, standard. The histoire de longue durée or histoire conjoncture, which the underlying data actually should be used to write, is usually linked, without any more thorough analysis of the nature of that link, to an

52 Sykes, Blood of the Isles, 288; cf. Sommer, It's a Living History.

53 See, e.g., Ehrenkodex »Ethische Grundsätze für archäologische Fächer « www.wsva.net/fileadmin/wsva/dokumente/ ehrenkodex_659_1.pdf (retrieved on 15 June 2016); cf. Beaudry, Ethical Issues in Historical Archaeology; Scarre and Scarre, Ethics of Archaeology.

54 It is claimed to be less problematic, because phenotype irrelevant, so-called junk DNA was investigated; e.g., Griffith and Harding, Interdisciplinary Approaches, 22; cf.; Harding et al., Viking DNA; Sommer, "Wer sind Sie wirklich?«, 56; cf. Dietrich, Origins of the Neutral Theory. Nadia Abu El-Haj expresses a very critical view of the neutrality of even so-called junk DNA (Abu El-Haj, Genetic Reinscription of Race; Abu El-Haj, Genealogical Science).

55 The opening statement in the text accompanying a short video that appeared on 26 November 2010 featuring the work of a project entitled »People of the British Isles«, funded by the Wellcome Trust, is worded as follows: »What does being British mean to a scientist?« (Nash, Genome Geographies, 193; see also www.youtube.com/watch?$\mathrm{v}=\mathrm{PCwHCMfyW88}$ (retrieved on 15 June 2016)).

56 For the project website see www2.le.ac.uk/projects/impact-of-diasporas/ (retrieved on 15 June 2016).

57 Schramm, Neue Technologien, 234.

58 Metaphorical term introduced in 1962 by Emile Zuckerkandl and Linus Pauling denoting a method in genetics which uses the mutation rates of biomolecules to deduce when two or more life forms diverged in prehistory. Unfortunately, mutation rates are non-constant. In addition, in order to provide specific dates, the molecular clock has to be calibrated with fossil or archaeological records (Zuckerkandl and Pauling, Molecular Disease); Ayala, Molecular Clock Mirages; cf. Sommer, History in the Gene.

59 E.g., Brather, Ethnische Interpretation, 344-354; Brather, Lindesfarne. 
histoire événementielle, whose characters and events then dominate the migration narratives. ${ }^{60}$ To give one example: the high proportion of the "genetic legacy of Vikings « found in the population of Wirral and West Lancashire has been linked to the expulsion of Norwegian Vikings from Dublin and their settlement in Wirral in 902 under the leader Ingimund. ${ }^{61}$

\section{Space}

Concepts of space underlying archaeological and genetic analyses are considerably more similar, however. A "methodological territorialism ${ }^{62}$ is often inherent in studies of both types, though it is easier to avoid in genetic history.

In archaeology, the findings related to a group of people with its lived social space are usually associated with a more-or-less clearly delimited territory. Designations of administrative and natural-geographical units often serve to localize these geographically. This is frequently associated with an amalgamation of the different kinds of spaces, which can be better separated analytically: social spaces, natural spaces and modern administrative spaces. Moreover, in many cases archaeologists address only the structural spaces, which are so nicely (re)producible in maps, while failing to address the spaces for movement hidden behind them. Furthermore, the use of information acquired from the location of finds is also indispensable for the field of archaeology. Localization will therefore always play an important role. In my view, however, rather than locations inside "container spaces", one should start from interrelated networks of locations, and if one does posit the existence of correlations between enclosed cultural spaces and features or boundaries of the natural landscape, one should always specify one's rationale for doing so. ${ }^{63}$ However, there is still a dearth of constructive approaches for conceptualizing and researching dynamic, overlapping scapes rather than static territories. Still, researchers studying the Viking period in particular have tended in recent years to focus more on analyses relating to individual archaeological sites or small geographical regions because these permit them to produce »denser « descriptions.

Geneticists also argue with territorial areas of distribution. These used to be defined mainly on a global or continental scale, ${ }^{64}$ but smaller scales are being used now as well, as the Wirral and West Lancashire project demonstrates. The term 'genome geography is understood as: "how, through the tools and practices of human genetics, bits of genomic sequence become associated with specific geographic locations, posited as the place of origin of people who possess these bits. ${ }^{65}$ Another argument put forth by population geneticists is that gradients of human genetic variation are geographically structured. ${ }^{66}$ People living closer together who, or rather, whose ancestors, did not migrate over long distances during the last centuries, or who were separated from other populations by topographical barriers,

60 Cf. Braudel, Geschichte und Sozialwissenschaften.

61 Though this event-oriented historical [ereignisgeschichtliche] interpretation is reported as merely »one version of events " in the paper aimed at the scientific community, it is discussed in considerably more detail than any other "version « in the popular science book Viking DNA, and is reinforced by the book's cover; Bowden et al., Excavating Past Population Structures, 302; Harding et al., Viking DNA, front cover illustration, 11, 16-18, 121. Cf. Harding, Ingimund's Saga.

62 Brenner, Beyond State-Centrism, 46; Langthaler, Orte in Beziehung.

63 Hofmann, Fundverbreitungen; cf. Krämer, Was eigentlich ist eine Karte?

64 Thomas, Gene-Flows and Social Processes, 51.

65 Fujimura and Rajagopalan, Different Differences, 7; cf. Nash, Genome Geographies.

66 Novembre et al., Genes Mirror Geography. 
are likely to bear greater similarity to one another than they do to people who live farther away. This results in the creation not only of genome geographies - usually mapped with reference to nation states - of present-day populations, but also of imagined geographies of ancient populations and their homelands ${ }^{67}$ In connection with data collection, therefore, there is a preference for drawing on "indigenous populations $:^{68}$ researchers seek proof of residence or, lately, stock their sample populations with people whose surnames are old and relatively rare, which increases the statistical probability of their local specificity. ${ }^{69}$ However, these days, scholars studying the British Isles during the Viking period assume that a variety of colonization strategies were pursued, and that responses to them were subject to regional and chronological variation..$^{70}$ Along with toponyms, various settlement and building forms in particular have been interpreted as indications of the composition of populations specific to each. Thus settlements have been termed Viking or Scandinavian, Hiberno-Norse, AngloScandinavian and Anglo-Saxon. ${ }^{71}$ Despite these questions, which are clearly worthy of research, so far only genetic studies based on entire regions instead of single settlements have been carried out.

In the context of the genetic analysis conducted for North-west England, researchers were able to work on a regionally differentiated basis and to some extent with "reconstructed" random samples from the Middle Ages, but for the necessary comparison with Scandinavia they drew only on data for the present-day population of Norway. ${ }^{72}$ The broad term "Viking" is thus geographically restricted in this study - although with reference back to the written sources.

\section{Mobility}

The object geographies of archaeologists and the genome geographies of geneticists are all based on specific notions of mobility. Though the early equation "pots equal people" has come under fire on multiple occasions,${ }^{73}$ it is still common to find specific names and cultures associated with specific artifacts. For instance, archaeologists often continue to interpret finds of oval brooches as an indicator of the presence of Scandinavian women in England, although the fibulae could have also been traded, given as gifts etc. ${ }^{74}$ The growing numbers of object biographies being published have made it increasingly clear that objects are not necessarily accompanied by their manufacturers or even by their former users when they travel. ${ }^{75}$ Selected material culture can serve as a marker of identities in certain situations, but

67 Nash, Irish DNA, 196.

68 Schramm, Neue Technologien - alte Kategorien, 244; Sommer, »Wer sind Sie wirklich?«, 66.

69 Bowden et al., Excavating Past Population Structures; King and Jobling, What's in a Name.

70 Richards, Viking Settlement in England, 372.

71 E.g., Fellows-Jensen, Scandinavian Settlement in England; Hall, Scandinavian Settlement in England; Richards, Identifying Anglo-Scandinavian Settlements; Wallace, Archaeological Identity.

72 Nash, Genome Geographies, 199-200.

73 Carol Kramer was already arguing against the equating of pots with people back in 1977 (Kramer, Pots and People); cf. Ucko, Introduction, 12.

74 E.g., Kershaw, Viking Identities, 216; cf. Lee, Viking Age Women.

75 E.g., Boschung et al., Biography of Objects; Gosden and Marshall, Cultural Biography of Objects; Hahn and Weiss, Mobility, Meaning and Transformation of Things; Kopytoff, Cultural Biography of Things. 
its interpretation must always be context-specific. Where once researchers thought in terms of human migration or the diffusion of ideas, today more and more researchers want to study the entire spectrum of mobility, though the interactions and effects of different kinds of mobility have not yet been adequately researched. ${ }^{76}$

Geneticists probably have it easier in this respect, since genes do indeed travel within the bodies of potentially mobile persons. However during the Viking period, the term Viking, while it did denote an activity, was not associated with a line of descent that can be localized territorially within present-day Scandinavia. These days, geneticists' interest is largely confined to spatial mobility and in our context to migration - also called demic diffusion, i.e., permanent changes of place of residence resulting in a population of descendants in a region far removed from the place of origin. Three basic premises underlie their work: (i) that migrations have more effects than other forms of mobility; (ii) that, in percentage terms, more people migrate in the modern age and in urban areas than did/do in earlier periods or in rural areas; and (iii) that the most significant population movements are known to us through archaeological and/or historical sources. However, since the so-called Anglo-Saxons invaded Britain before the Vikings, and differentiating between these two "migration movements " has proven difficult, the isolation desired can only be achieved by concentrating on "the " Norwegians for the time being. ${ }^{77}$ This flaw is very important to keep in mind, because written and material evidence alike make it clear that England and Denmark were closely linked by many different networks - a fact that this Norwegian focus necessarily ignores.

In the context of debates about transnationality and globality, diasporas, as one possible consequence of migrations, have attracted the interest of archaeologists, historians and literary scholars as well as geneticists. ${ }^{78}$ However, researchers interested in diasporas seldom consequentially examine their influence on the land of origin; doing so would require them to thoroughly reexamine the questions about provenience of material culture that keep cropping up. In that case, for instance, the decision to use modern-day Norwegians for genetic constructions of a Viking period diaspora in England would no longer appear so straightforward. Questions about male and female mobility have also arisen in connection with the differences in the results obtained in analyses of mtDNA and Y-DNA. ${ }^{79}$ Traditionally, both population geneticists and archaeologists have tended to consider men as more likely to be interested in migration than women $;^{80}$ very rarely has research looked at what such assumptions imply for the populations in question. Moreover, new results coming in from isotope analyses have called into question the degree of validity of generalized statements about the relationship between gender and mobility/migration. ${ }^{81}$

76 Gramsch, Culture, Change, Identity; Kaiser and Schier, Mobilität und Wissenstransfer.

77 Bowden et al., Excavating Past Population Structures; Leslie et al., Fine-Scale Genetic Structure; Winney et al., People of the British Isles.

78 Cf. Abrams, Diaspora and Identity; Jesch, Viking Diaspora; Sommer, Population-Genetic Trees, Maps, and Narratives; Sørensen, Gender, Material Culture, and Identity; see also the website of the project »The Impact of Diasporas«: www2.le.ac.uk/projects/impact-of-diasporas (retrieved on 26 April 2016).

79 Helgason et al., Estimating Scandinavian and Gaelic Ancestry; Helgason et al., MtDNA and the Islands; Wilson et al., Genetic Evidence.

80 Koch, Geschlechterrollen zwischen den Zeilen; Sommer, »Wer sind Sie wirklich?«, 64.

81 Johannes Krause, Die genetische Herkunft der Europäer: Migration in der Vorgeschichte, lecture given on 1 June 2016, as part of the lecture series Migration. Wanderungsbewegungen vom Altertum bis in die Gegenwart; Kerstin Hofmann, Identität durch Mobilität? Wikinger in Großbritannien, lecture given on 6 July 2016: migration.hypotheses.org (retrieved on 30 October 2016). E.g., Sjögren et al., Diet and Mobility. 


\section{Identity}

Diverging approaches to time, space and mobility have repercussions for the conception of identity associated with them. Following the philosopher Vincent Descombes, one can distinguish at a fundamental level among three different questions associated with the riddle of identity: (i) who/what is this; (ii) who am I; and (iii) who are we. ${ }^{82}$ While the first question permits a pure identification from a bird's eye view, the other two cannot be answered without examining why someone identifies with something. Yet answering even the first question requires clarification of what is called the ssortal dependency of individuation $<{ }^{83}$ i.e., the question "what does it mean for an $\mathrm{x}$ of the sort/type/category $\mathrm{y}$ to continue to exist?«, or in our case here, "what does it mean for (ancient and/or modern) Vikings to exist?", and to which kind of category do they belong? What is needed, therefore, is not only a synchronic but also a diachronic principle of individuation. I would like to clarify this briefly in the following.

History is one of several fields that have taken up narratological theories and concepts in recent years ${ }^{84}$ In this context, historian Felix Wiedemann, whose fields are modern history and the history of science and scholarship, has proposed that we differentiate between historical actors and historiographical protagonists. ${ }^{85}$ Applying this suggestion to our example, both modern Vikings and ancient Vikings would, in the first instance, be nothing other than the protagonists of historiographical narratives. ${ }^{86}$ Pirates as well as explorers, traders and settlers of the eighth to eleventh centuries, who came from the area now known as Northern Europe, on the other hand, would be historical actors, just as other persons who lived in the period would be. The hunt for, and above all, the definition of Viking DNA, however, results in the "naturalization" of protagonists of historiographical narratives and their equation with historical actors. This is because ultimately researchers need stories - whether they be factual narratives provided by historians or even myths - if they are to produce an extensive interpretation of the nucleotide sequences that they treat as objective or neutral. ${ }^{87}$ Similar considerations apply, of course, for the interpretation of material cultures and historical texts. So this practice of essentializing identities was not and is not now unusual, even in the work of a purely archeological or historical character.

In connection with the ethnological critique of so-called primordialist approaches (Fig. 2), archaeologist Lynn Meskell, for one, has specifically criticized the recourse to supposed biological facts as a way of "naturalizing power $4{ }^{88}$ Meskell also defined the systematic deconstruction of these supposed facts as one of the key tasks of an archaeology of identity ${ }^{89}$

82 Descombes, Rätsel der Identität.

83 Wiggins, Sameness and Substance Renewed, 22.

84 E.g., Saupe and Wiedemann, Narration und Narratologie; Spinozzi and Hurwitz, Discourses and Narrations in Biosciences; Strohmaier, Kultur - Wissen - Narration; White, Auch Klio dichtet.

85 Wiedemann, Völkerwellen und Kulturbringer; cf. Wiedemann, Stones and Stories; Wiedemann et al., Wanderungsnarrative.

86 Cf. Nelson, England and the Continent.

87 Sommer, Angewandte Geschichte auf genetischer Grundlage, 140-142; Sommer, History in the Gene; cf. Morning, And You Thought We Moved beyond all That?

88 Yanagisako and Delaney, Naturalizing Power.

89 Meskell, Archaeologies of Identity. 


\begin{tabular}{|l|l|}
\hline primordialist definition of identity & (de)constructivist definition of identity \\
\hline immediate and primary, acquired by birth & $\begin{array}{l}\text { discursive practice, } \\
\text { generated by demarcation }\end{array}$ \\
\hline belonging & strategy, legitimation, power \\
\hline change only slowly & easy to change, flexible \\
\hline essence, substance & code, social artifact \\
\hline
\end{tabular}

Fig 2. Primordialist versus (de)constructivist definition of identity

In addition, some years ago, Adam $\mathrm{T}$. Smith issued an impressive call for the »end of the essential archaeological subject « and warned of the dangers of transferring present-day categories of identity onto the past..$^{90}$ In archaeology today, the usual answer to the question of what characterizes a collective identity is situation- and context-specific self-identification. ${ }^{91}$ In this understanding of collective identity, one person can put on, but also cast off again, multiple identities. Thus, the historical identity of Vikings, if there ever was such a thing, would not have been tied to a biological organism or the rules of inheritance associated with it. Establishing a link between genes and identity using archaeology's wider concept of Viking identity as a specific set of material culture would not be so simple either: one would first have to show a causal relation between the use of specific material culture and biological descent, since the latter is the sortal determination of identity in genetics. ${ }^{92}$

There are a great many different definitions of sortal dependencies in the worlds we inhabit, and there were a great many of them in the worlds that existed in the past. Until we are familiar with them and their interdependencies, shared names only conceal what we seek to illuminate. Semantic shorthands may be helpful in "the universally pre-logical logic of practice $«,{ }^{93}$ but for academic research they are usually more of a hindrance.

90 Smith, End of the Essential Archaeological Subject.

91 E.g., Brather, Ethnische Interpretation, 97; Díaz-Andreu and Lucy, Introduction, 1; Jones, Archaeology of Ethnicity, 13.

92 The fact, that one of the few things that we know about some of these people's sense of themselves is that the they thought they spoke the same language - the so-called sdønsk tungar, >Danish tongue - could be an indication of self-identification (cf. Jesch, Viking Diaspora), but is not a sufficient due cause for an existing supra-regional identity of inhabitants of Scandinavia and their overseas settlements. Language is certainly an important communication medium, but again it is necessary to analyze the concrete relations between language, geography and descent.

93 Bourdieu, Logic of Practice, 12. 


\section{Identity politics}

After this rather cursory and greatly simplified discussion of different conceptions of time, space and mobility and their repercussions for the concept of identity one uses, I would now like to turn to identity politics.

\section{Gene and identity narrative in the public sphere}

Genetic anthropology has become tangled up in the identity discourse to an even greater degree than that discussed with respect to archaeology and archaeological research, ${ }^{94}$ according to Marianne Sommer, a scholar who studies the history of science and scholarship. ${ }^{95}$ While there has been a great deal of theoretical discussion and speculation about the potential impacts of the science of genetics - ranging from the production of biosociality, ${ }^{96}$ to a restoration and remediation of the identity discourse ${ }^{97}$ on to the danger of a new eugenics and the racialization and essentialization of ethnicity ${ }^{98}$ - thus far actual case studies have been few and far between.$^{99}$ This makes it all the more gratifying that the new interdisciplinary project "The Impact of Diasporas on the Making of Britain" envisions a systematic analysis of the impacts of genetic research on the general public. ${ }^{100}$ I will therefore only mention two of the discussions conducted in the media in which the linkages between personal and collective identities on the one side, and genes, ethnic groups and nations and the assessment thereof on the other have emerged with particular clarity.

In Scotland, as in many other regions of the world, the supply of sperm donated for the purpose of artificial insemination failed to keep up with demand in the late 1990 s. ${ }^{101}$ As a result, physicians came up with a plan to import sperm from a Danish sperm bank. The media picked up the story under headlines like "The Viking Baby Invasion «. ${ }^{102}$ They also evoked images of earlier contributions by Northern Europeans to the British gene pool, one of which was put on paper by David Austin in a cartoon printed in the Guardian, showing a Viking, who has just come ashore from his dragon ship, telling a woman: »We are here to burn pillage and donate. $\aleph^{103}$ The media hype also led to a temporary boom in sperm donation by Scottish

94 Cf. Brather, Ethnische Interpretationen; Gardner, Paradox and Praxis.

95 Sommer, „Wer sind Sie wirklich?«, 53; she believes that genetic anthropology is bound up in identity politics, from A as in "Antragstellung " (applying [for a grant]) to $\mathrm{Z}$ as in "Zusammenfassung der Forschungsresultate (summarizing the research results).

96 Rabinow, Artificiality and Enlightenment.

97 Bolter and Grusin, Remediation; Scully et al., Remediating Viking Origins.

98 Bradby, Genetics and Racism; Morning, And You Thought We Had Moved beyond All That; Simpson, Imagined Genetic Communities.

99 Positive exceptions are Scully et al., Remediating Viking Origins; Sommer, »Wer sind Sie wirklich?«.

100 For further details see: www2.le.ac.uk/projects/impact-of-diasporas (retrieved on 26 April 2016). For an example of what kind of reactions the work of Richard Jones provoked in France see www.theguardian.com/world/2015/ jun/16/hunt-for-viking-dna-among-normandy-residents-riles-anti-racism-activists; http://www.anthrogenica. com/showthread.php?6993-Normandy-Most-convincing-viking-markers-present-in-59-of-the-samples (retrieved on 30 October 2016). (Jones was part of the Leicester Impact of Diaspora project.)

101 Cf. Simpson, Imagined Genetic Communities, 4-5; Sommer, Angewandte Geschichte, 143.

102 Hillmore, Viking Baby Invasion.

103 Simpson, Imagined Genetic Communities, 4. 
men. It is difficult to tell just what motivated these donors. Apparently, though, some of them felt that it was important for the genes being passed on to be Scottish. For instance, one Scot who lived in London offered to travel to Glasgow regularly in order to donate. On the other hand, one Glasgow Herald reader wrote in to say that it did not matter where the sperm came from, as long as it came from a nation that could play soccer. Just an anecdote from the last millennium, one might think, if it were not for the fact that the discussion broke out again only recently, triggered by the BBC broadcast "Modern Times: The Vikings are Coming “. ${ }^{104}$

As a second example I would like to point to the international project on surnames and Y-DNA initiated by hobby genealogists and carried out by FamilyTreeDNA, a private sector business. ${ }^{105}$ Contrary to expectations, the project's certainly questionable finding was that the Barra-based McNeil clan is descended not from Niall of the Nine Hostages, the legendary Irish king, but from Vikings. This news triggered newspaper articles and discussions all over the world early this year. ${ }^{106}$ Reactions of the sampled individuals and other members of the McNeil family varied greatly, running the gamut from rejection to references to the Irish maternal line, and from playful approaches to the presumed new line of descent all the way through to acceptance and even a willingness to rewrite the family's history. ${ }^{107}$

Many people, then, are able to wear, shed or recombine different identities like garments, without placing any great importance on it. ${ }^{108}$ As individuals, we appear to be so well practiced as wanderers among major collective memories ${ }^{109}$ in the free market of collective identities on offer, that we often have no trouble embedding a new genetic identity into our multiple I-narratives. However, when central concepts relating to the identity of individuals or groups that struggle for recognition are involved, the results can lead to profound transformations of the I-consciousness and we-consciousness. The Vikings would not appear to present a very apt example for this: they may have had a bad reputation in the contemporary sources written by their victims, but they enjoy an astounding degree of popularity today (one responsible for the predominantly lighthearted tone in which the danger of the invasion of Viking babies was discussed).

\section{Academic tribes and territories}

Identity politics is not confined to the public sphere, however: it also plays out in the hallowed halls of alma mater. Immanuel Kant was already reflecting on the "conflict of the faculties « back in $1798 .{ }^{110}$ Later, Norbert Elias noticed that academic departments are similar in some respects to sovereign states, ${ }^{111}$ and then in 1989 Tony Becher published a study on

104 Brian, Invasion of the Viking Babies; Johnston, Rise of the Baby Vikings.

105 For further information see: www.familytreedna.com/public/MacNeil?iframe=ysnp (retrieved on 28 April 2016). 106 E.g., Ayers, Scandinavian MacNeils; Kane, DNA Tests Prove.

107 By way of illustration, here are some of the reactions cited in some of the newspaper articles: »I nervously awaited the results, and was emotionally devastated when we received them. [...] I found solace in the fact that, if not a Celt, I am nevertheless a Gael« (Paul McNeil); »... my two Irish grandmothers will ensure the Irish« (Stephen McNeil); "I will be adding a new horned helmet to my kilt ensemble« (Ian MacNeil); "I'm pretty good with being of Viking descent. ... You are what you are« (Michael MacNeil); "But mother nature knows who we are. Oral history is wonderful and often there is truth in it. But everybody's family history is in their DNA« (Vincent MacNeil).

108 Sommer, »Wer sind Sie wirklich?«, 54-62; cf. Scully et al., Remediating Viking Origins.

109 »Wanderer zwischen Großgedächtnissen« (Patzel, »Alle Erinnerung ist Gegenwart«, 192).

110 Kant, Streit der Fakultäten.

111 Burke, Norbert Elias. I would like to take this opportunity to thank Hans-Peter Hahn for the inspiring discussions upon interdisciplinarity and the bibliographical reference. 
several different disciplines in Britain and the USA under the title "Academic Tribes and Territories « ${ }^{112}$ In 1950, Charles Percy Snow diagnosed the emergence of two cultures at odds with each other, the sciences and the humanities. ${ }^{113}$ Snow's thesis in particular has been labeled unproductive on several occasions and is considered outdated, ${ }^{114}$ and rightly so in my view given the present-day plurality in cultures of knowledge. Yet it is a notion referred to again and again by scholars defining the cognitive identity of archeology or discussing the possibilities of collaboration between archaeologists and geneticists. ${ }^{115}$ It may be that part of the explanation lies within archaeology itself, that is, in a divergence - within a discipline that supposedly bridges the sciences and the humanities - between one branch tending to rely more on natural-science methods, and another branch leaning more towards the humanities/literary studies. ${ }^{116}$ It is important to be aware in this respect that the research on identity, diasporas and cultural contacts at issue here is currently closely linked to the humanities and cultural studies, which means that the extensive criticism of genetic anthropology is also an expression of internal conflicts within archaeology.

However, academic primacy, and with it the prerogative of interpretation, are also at stake. Over the last few decades archaeology has held clear title to these for the period of what is called pre- and proto-history. A new and very ambitious player has entered the arena recently though, one that has reaped a great deal of premature praise and garnered stupendous amounts of research funding. Struggles for recognition and in defense of status, i.e., statements within the scope of identity politics, are to be expected here, but they should not be permitted to distract scholars from their proper work for long. A historical comparison with the situation associated with the introduction of radiocarbon analysis, ${ }^{117}$ and also with that during the establishment of medieval archaeology as distinct from or as part of the field of history, ${ }^{118}$ would certainly bring to light many interesting parallels and identify certain pitfalls we should watch out for.

In my view, however, if the desired genuine collaboration between archaeology and genetic anthropology is to take place, it is important that scholars on both sides become familiar with the epistemological, methodological, conceptual and terminological ${ }^{119}$ differences

112 Becher, Academic Tribes and Territories; resp. Becher and Trowler, Academic Tribes and Territories.

113 Snow, Two Cultures; cf. Kreuzer, Literarische und naturwissenschaftliche Intelligenz; Reinalter, Natur- und Geisteswissenschaften.

114 Meier and Tillessen, Von Schlachten, Hoffnungen und Ängsten, 26-27; cf. Bachmaier and Fischer, Glanz und Elend der zwei Kulturen; Mittelstraß, Häuser des Wissens.

115 Pluciennik, Clash of Cultures?; Samida in: Eggert and Samida, Zum historischen Potential des Materiellen, 199200; cf. but without mentioning Snow: Samida and Eggert, Über Interdisziplinarität; Samida and Eggert, Archäologie als Naturwissenschaft?.

116 Succinctly characterized by Ulrich Veit as archaeologist-as-scientist and archaeologist-as-author (Veit, >Mission Impossible!«, 100); cf. Gramsch, Jenseits der »Zwei Kulturen«. There is a certain trend towards new holistic approaches though, e. g. Hofmann, Anthropologie als umfassende Humanwissenschaft; Hodder, Entangled; Kristiansen, Genes versus Agents.

117 Cf. Delley, Au-delà des chronologies; Delley, Long Revolution of Radiocarbon; Renfrew, Before Civilization.

118 Cf. Dymond, Archaeology and History; Jankuhn and Wenskus, Geschichtswissenschaft und Archäologie; esp. Wenskus, Randbemerkungen; Burmeister and Müller-Scheeßel, Fluchtpunkt Geschichte.

119 Just by way of example, let me refer here to the different meanings of the words colonization and origins, which frequently result in misunderstandings; see also Gautier, Du danger des mots transparents; Hofmann, What Have Genetics Ever Done for Us?, 460. 
between the two academic subjects, as well as with the differences associated with pragmatic concerns that arise from the differing research traditions. With this knowledge, we will hopefully be able to work together to overcome those differences in practice and to use them constructively. ${ }^{120}$ The scope of this paper allows no more than a brief list of a few points of divergence in simple terms: ${ }^{121}$ there are differing epistemological positions (constructivism vs. realism); different sources and their ties to individuals and groups; differences in research strategies when dealing with complexity (starting with initially simple/testable vs. already complex hypotheses); different focuses on geographical and chronological units; and, last but not least, differing traditions with respect to publications and lecture styles (Fig. 3). Together, these hold out more than enough potential to result in a failure to understand or misunderstand, but also for polemics, such as those launched from both sides in recent years in the battle over attention, funding or simply the "right « way to conduct research. ${ }^{122}$

\begin{tabular}{|c|c|c|}
\hline & $\begin{array}{l}\text { archaeology - } \\
\text { humanistic branch }\end{array}$ & genetic anthropology \\
\hline epistemology & constructivism & realism \\
\hline research strategy & $\begin{array}{l}\text { like to deal with the already } \\
\text { complex }\end{array}$ & $\begin{array}{l}\text { from simple hypotheses and dicho- } \\
\text { tomizing question to complexity; } \\
\text { major focus on testability }\end{array}$ \\
\hline data & $\begin{array}{l}\text { material culture (produced and } \\
\text { used by various persons and } \\
\text { communities) }\end{array}$ & $\begin{array}{l}\text { genes (within individual bodies, } \\
\text { passed from generation to genera- } \\
\text { tion) }\end{array}$ \\
\hline $\begin{array}{l}\text { scales } \\
\text { (geographical, } \\
\text { chronological) }\end{array}$ & $\begin{array}{l}\text { focus on the local, } \\
\text { regional decades/ } \\
\text { centuries }\end{array}$ & $\begin{array}{l}\text { focus on } \\
\text { the global/continental/national } \\
\text { milleniums }\end{array}$ \\
\hline $\begin{array}{l}\text { publishing } \\
\text { traditions }\end{array}$ & $\begin{array}{l}\text { slow; long papers or books, } \\
\text { single authors; regional jour- } \\
\text { nals; multilingual; main results } \\
\text { normally at the end of the paper } \\
\text { (conclusion) }\end{array}$ & $\begin{array}{l}\text { quick; preliminary results, short } \\
\text { papers, many contributors; inter- } \\
\text { national journals; English; main } \\
\text { results normally at the beginning of } \\
\text { the paper }\end{array}$ \\
\hline lecture style & $\begin{array}{l}\text { reading out fully formulated } \\
\text { texts, text-heavy presentations }\end{array}$ & $\begin{array}{l}\text { free speech, structured, many } \\
\text { statistics }\end{array}$ \\
\hline
\end{tabular}

Fig. 3: Differences in the research between the humanistic branch of archaeology and that of genetic anthropology

120 A similar call was issued by de Chadarevian, Genetic Evidence and Interpretation, 302; Cf. Fuest, Ethnologie in der Arena; Schmidt, Towards a Philosophy of Interdisciplinary.

121 Cf. Brown and Pluciennik, Archaeology and Human Genetics, 103-104.

122 E.g., Evison, Genetics, Ethics and Archaeology; Hedges, Comment; Mirza and Dungworth, Potential Misuse of Genetic Analyses; Pluciennik, Genetics, Archaeology and the Wider World. Cf. de Chadarevian, Genetic Evidence and Interpretation. Unfortunately, in my opinion, these also include a statement made in the announcement of a joint workshop for geneticists, historians and archaeologists: »These geneticists promise answers: using analysis of DNA to discover what really< happened during the Bronze Age and the Viking sagas and replace `biased histories with cold, hard data« (Nature Publishing Group, Source Material). 
Conclusion: Should we stay with or leave the troubled helix?

Yet is it sensible for us, as archaeologists, to continue to actively engage with the »troubled helix ${ }^{123}$ and its study at all? Might it be better for us to simply ignore it - due, e.g., to time considerations or the complexity involved? Let me refer to an expression from Donna Haraway that the cultural anthropologist Katharina Schramm recently introduced to the discussion about new technologies and old categories: "staying with the trouble«. ${ }^{124}$ In the past, scholars, particularly German-speaking archaeologists, spent far too much time refining problem-avoidance strategies and, as a result, failed to adequately fulfill their actual social task. Although much has been done in recent years - as many new projects demonstrate, including those studying the Vikings in Great Britain - the situation remains complicated. This should certainly have become apparent through my comments about the widely diverging practices associated with the constitution and assertion of identities. Like Donna Haraway, though, I see it as our common task and challenge to develop methods and theories that are both testable and capable of analytically capturing the complexity of life, ${ }^{125}$ and to find descriptions that are not reductionist or redundant, or both. ${ }^{126}$ Many geneticists take up master narratives and categories that were formulated and shaped in the past by historians and archaeologists. In this respect, we historians and archaeologists must demonstrate the same sense of responsibility that we are now demanding from geneticists. We must do so not only in our academic publications on our research findings, but also in the popular works we write on those topics. ${ }^{127}$ In other words, we have to make our research more easily accessible to and more easily comprehensible by both the scientific community and the general public in a way that limits the potentials for distortion and political instrumentalization.

The constructivist concept of identity often preferred by scholars of humanities and the social sciences these days is weighted with discourse and voluntarism. To avoid earlier biologisms, and due to our current sociopolitical situation, we have tended to ignore our bodies as well as other so-called biological factors. This is not without its dangers over the long term however. On the contrary, it has become imperative that we join together to subject certain questions to rigorous scrutiny, such as how the body and identity or sexual and social reproduction interact with and shape one another. ${ }^{128}$ This task requires us to go beyond modernity's binary distinction between the biological and the social.

Through my discussion of the case of Vikings and the research on them, I have also shown how we have, by using semantic shorthand and applying one shared name, facilely equated and without considering the interactions among them - historical, linguistic, narratological and socio-cultural and biological entities whose natures are defined quite differently. This error has often been coupled with a naturalization and essentialization of identities. Yet what is interesting, in my opinion, is not the existence of identities, but their historicization, the highly complex interplay among the widest variety of actors and elements and the doing und undoing of differences. ${ }^{129}$

123 Marteau and Richards, Troubled Helix.

124 Haraway, When Species Meet; Haraway, When Species Meet; Schramm, Neue Technologien, 235.

125 See also Grupe and Harbeck, Isotopen- und DNA-Analysen, 22.

126 Haraway, When Species Meet; cf. Lidén and Eriksson, Archaeology vs. Archaeological Science.

127 Wiwjorra, Ethnische Anthropologie, 140.

128 Voss, What's New?, 663-664.

129 Cf. Hirschauer, Un/doing Differences; Pohl, Comparing Communities. 
We are still all too often falling victim to numerous identity traps (most of which we ourselves constructed), whether they take the form of such historical designations as vikingr, which we use for multiple referents and interpret in ethnic terms, ignoring other aspects; or the forms of old myths, categories, concepts or axioms; or even the pitfalls that result from the boundaries established between academic fields. The systematic exposure of these traps would take us an important step in the right direction. Studies in the sociology of knowledge and the history of science and scholarship, as well as ideology-critical questioning, can surely contribute here. But the examination of whether a cultural marker in a specific region, such as an inherited name, is also associated with shared gene patterns, can also further this project. Moreover, a combination of different bio-archaeological investigations, such as analyses of modern and ancient DNA, as well as stable isotope analyses, would certainly also be helpful for the study of protohistory. ${ }^{130}$ It would allow researchers to grapple with the question, still too rarely asked, of how large-scale population movements interact with the spatial and social mobility of individuals. ${ }^{131}$ Another promising approach, in my view, would be to attempt to tell not one sweeping meta-narrative of the kind so often dominated by the history of events, but a multitude of different stories that would more accurately reflect differing approaches and varying quality of our sources. The plausibility of these stories could then be assessed case by case, rather than universally. Hence, we have a great deal of work to do: conferences like "Genetic History: A Challenge to Historical and Archaeological Studies" can shed light on the various pitfalls and, hopefully, contribute to more intense and productive dialog.

\section{Acknowledgments}

This contribution was part of my postdoctoral research at the Cluster of Excellence »Topoi. The Formation and Transformation of Space and Knowledge « financed by the Deutsche Forschungsgemeinschaft at Berlin. First of all, I would like to thank Jörg Feuchter and Stefanie Samida for inviting me to the conference "Genetic History: A Challenge to Historical and Archaeological Studies" in Berlin. I am very grateful to them and to the participants of the conference for their inspiring comments on my paper. Further I would like to thank Hans-Joachim Gehrke, Jörg Feuchter, Cătălin Popa, Philipp von Rummel, Roland Steinacher, Philipp Stockhammer and Felix Wiedemann for stimulating discussions about genetic history, identity politics and narratology. Moreover, I am very grateful to Gisela Eberhardt, Larissa Förster, Hans-Peter Hahn, Lara K. Keuck, Werner Kogge, Katharina Schramm, Blandina C. Stöhr and a reviewer for valuable hints and bibliographical references. Alison Borrowman produced the translation of my German manuscript.

130 Hofmann, What Have Genetics ever Done for Us?, 464.

131 Müller puts this in similar terms (Müller, Kossinna, Childe and aDNA, 36). 


\section{References}

Abrams, Lesley, Diaspora and Identity in the Viking Age, Early Medieval Europe 20/1 (2012) 17-38.

Abu El-Haj, Nadia, The Genetic Reinscription of Race, Annual Review of Anthropology 36/1 (2007) 283-300.

Abu El-Haj, Nadia, The Genealogical Science: The Search for Jewish Origins and the Politics of Epistemology (Chicago, 2012).

Adam von Bremen, Gesta Hamburgensis ecclesiae pontificum, ed. Werner Trillmich and Rudolf Buchner, Quellen des 9. und 11. Jahrhunderts zur Geschichte der Hamburgischen Kirche und des Reiches, Ausgewählte Quellen zur Deutschen Geschichte des Mittelalters 11 (Darmstadt, 1968).

Andersson, Thorsten, Wikinger. Sprachlich, in: Johannes Hoops (ed.), Reallexikon der Germanischen Altertumskunde 35 (second edition), (Berlin, 2007) 687-697.

Ayala, Francisco J., Molecular Clock Mirages, BioEssays 21/1 (1999) 71-75.

Ayers, Tom, The Scandinavian MacNeils: Families Trace Roots back to the Vikings, The Chronicle Herald, [online] 21 January 2015. Retrieved on 28 April 2016: thechronicleherald.ca/novascotia/1264615-the-scandinavian-macneils-families-trace-roots-back-to-the-vikings.

Bachmaier, Helmut and Fischer, Ernst Peter (eds.), Glanz und Elend der zwei Kulturen. Über die Verträglichkeit der Natur- und Geisteswissenschaften, Konstanzer Bibliothek 16 (Konstanz, 1991).

Bamshad, Michael, Wooding, Stephen, Salisbury, Benjamin A. and Stephens, J. Claiborne, Deconstructing the Relationship between Genetics and Race, Nature Reviews. Genetics 5/8 (2004) 598-609.

Beaudry, Mary C., Ethical Issues in Historical Archaeology, in: Teresita Majewski and David Gaimster (eds.), International Handbook of Historical Archaeology (New York, 2009) 17-29.

Becher, Tony, Academic Tribes and Territories: Intellectual Enquiry and the Cultures of Disciplines (Milton Keynes, 1989).

Becher, Tony and Trowler, Paul, Academic Tribes and Territories: Intellectual Enquiry and the Culture of Disciplines (second edition), (Philadelphia, 2001).

Beyer, Jürgen, Pfadabhängigkeit. Über institutionelle Kontinuität, anfällige Stabilität und fundamentalen Wandel, Schriften aus dem Max-Planck-Institut für Gesellschaftsforschung 56 (Frankfurt a. M., 2006).

Böldl, Klaus, Wikinger. Definition des W.-Begriffs, in: Johannes Hoops (ed.), Reallexikon der Germanischen Altertumskunde 35 (second edition), (Berlin, 2007) 697-709.

Bolter, Jay David and Grusin, Richard, Remediation: Understanding New Media (Cambridge/ Mass., 2000).

Boschung, Dietrich, Kreuz, Patric A. and Kienlin, Tobias (eds.), Biography of Objects: Aspekte eines kulturhistorischen Konzepts, Morphomata 31 (Paderborn, 2015).

Boschung, Dietrich, Busch, Alexandra W. and Versluys, Miguel J. (eds.), Reinventing "The Invention of Tradition"? Indigineous Pasts and the Roman Present, Morphomata 32 (Paderborn, 2015).

Bourdieu, Pierre, The Logic of Practice (Stanford, 1990). 
Bowden, Georgina R., Balaresque, Patricia, King, Turi E., Hansen, Ziff, Lee, Andrew C., Pergl-Wilson, Giles, Hurley, Emma, Roberts, Stephen J., Waite, Patrick, Jesch, Judith, Jones, Abigail L., Thomas, Mark G., Harding, Stephen E. and Jobling, Mark A., Excavating Past Population Structures by Surname-Base Sampling: The Genetic Legacy of the Vikings in Northwest England, Molecular Biology and Evolution 25/2 (2008) 301-309.

Bradby, Hannah, Genetics and Racism, in: Marteau and Richards, Troubled Helix, 295-316.

Brather, Sebastian, Lindisfarne 793 als Beginn der Wikingerzeit? Kulturentwicklung und Ereignisgeschichte im Vergleich, Zeitschrift für Archäologie des Mittelalters 31 (2003) 39-60.

Brather, Sebastian, Ethnische Interpretationen in der frühgeschichtlichen Archäologie. Geschichte, Grundlagen und Alternativen, Ergänzungsbände zum Reallexikon der germanischen Altertumskunde 42 (Berlin, 2004).

Braudel, Fernand, Geschichte und Sozialwissenschaften. Die longue durée [1958], in: Claudia Honegger (ed.), Schrift und Materie der Geschichte. Vorschläge zur systematischen Aneignung historischer Prozesse (Frankfurt a. M., 1977) 47-85.

Brenner, Neil, Beyond State-Centrism? Space, Territoriality, and Geographical Scale in Globalization Studies, Theory and Society 28/1 (1999) 39-78.

Brendler, Silvio, Identity of Name(s) as a Crucial Problem in Name Studies, or: Towards the Recognition of Onymic Identity as a Principal Onomastic Concept, in: Botolv Helleland, Christian-Emil Ore and Solveig Wikstrøm (eds.), Names and Identities, Oslo Studies in Language 4/2 (Oslo, 2012) 29-44.

Brian, Kate, Invasion of the Viking Babies. With a Growing Demand for Donor Fathers, Women are Turning to Danish Sperm Banks, The Telegraph, [online] 23 June 2014. Retrieved on 28 April 2016: www.telegraph.co.uk/women/womens-life/10918344/Invasion-of-the-Viking-babies.html.

Brink, Stefan and Price, Neil S. (eds.), The Viking World (London, 2008).

Brown, Keri A. and Pluciennik, Mark, Archaeology and Human Genetics: Lessons for Both, Antiquity 75/287 (2001) 101-106.

Burke, Peter, Norbert Elias and the Social History of Knowledge, Human Figurations: Longterm Perspectives on the Human Condition 1/1 (2012) 7-17. Retrieved on 28 April 2016: http://hdl.handle.net/2027/spo.11217607.0001.102.

Burmeister, Stefan and Müller-Scheeßel, Nils (eds.), Fluchtpunkt Geschichte. Archäologie und Geschichtswissenschaft im Dialog, Tübinger Archäologische Taschenbücher 9 (Münster, 2011).

Cancik-Kirschbaum, Eva and Wiedemann, Felix, Historische Variablen und narrative Identität. Überlegungen zur historiographischen Namensgebung in den Altertumswissenschaften (in preparation).

Carroll, John M., What's in a Name? An Essay in the Psychology of Reference (New York, 1985).

Certeau, Michel de, The Writing of History (first edition: L' Ecriture de l' Histoire, Paris, 1975) (New York, 1988).

Cesana, Andreas, Geschichte als Entwicklung? Zur Kritik des geschichtsphilosophischen Entwicklungsdenkens, Quellen und Studien zur Philosophie 22 (Berlin, 1988).

Chadarevian, Soraya de, Genetic Evidence and Interpretation in History, BioSocieties 5/3 (2010) 301-305.

Debus, Friedhelm, Namen in literarischen Werken. (Er- )Findung - Form - Funktion, Abhandlungen der Geistes- und Sozialwissenschaftlichen Klasse 2 (Mainz, 2002). 
Delley, Géraldine, Au-delà des chronologies. Des origines du radiocarbone et de la dendrochronologie à leur intégration dans les recherches lacustres suisses, Archéologie neuchâteloise 53 (Hauterive, 2015).

Delley, Géraldine, The Long Revolution of Radiocarbon as Seen through the History of Swiss Lake-Dwelling Research, in: Gisela Eberhardt and Fabian Link (eds.), Historiographical Approaches to Past Archaeological Research, Berlin Studies of the Ancient World 32 (Berlin, 2015) 95-114.

Descombes, Vincent, Die Rätsel der Identität (Berlin, 2013).

Díaz-Andreu, Margarita and Lucy, Sam, Introduction, in: Margarita Díaz-Andreu, Sam Lucy, Staša Babić and David N. Edwards (eds.), The Archaeology of Identity: Approaches to Gender, Age, Status, Ethnicity and Religion (London, 2005) 1-12.

Dietrich, Michael R., The Origins of the Neutral Theory of Molecular Evolution, Journal of the History of Biology 27/1 (1994) 21-59.

Downham, Clare, "Hiberno-Norwegians« and »Anglo-Danes«: Anachronistic Ethnicities in Viking Age England, Mediaeval Scandinavia 19 (2009) 139-169.

Dymond, David P., Archaeology and History: A Plea for Reconciliation (London, 1974).

Eggers, Hans Jürgen, Einführung in die Vorgeschichte (München, 1959).

Eggert, Manfred K. H., Prähistorische Archäologie. Konzepte und Methoden (Tübingen, 2001).

Eggert, Manfred K. and Samida, Stefanie, Zum historischen Potential des Materiellen. Schriftliches Interview von Doreen Mölders (AG TidA), in: Kerstin P. Hofmann, Thomas Meier, Doreen Mölders and Stefan Schreiber (eds.), Massendinghaltung in der Archäologie. Der material turn und die Ur- und Frühgeschichte (Leiden, 2016) 197-214.

Evison, Martin P., Genetics, Ethics and Archaeology, Antiquity 70/269 (1996) 512-514.

Fehr, Hubert. Germanen und Romanen im Merowingerreich. Frühgeschichtliche Archäologie zwischen Wissenschaft und Zeitgeschehen, Ergänzungsbände zum Reallexikon der germanischen Altertumskunde 68 (Berlin, 2010).

Fellows-Jensen, Gillian, Scandinavian Settlement in England: The Evidence of Place-Names and Personal Names, in: Henri Galinié (ed.), Les mondes normands (VIIIe-XIIe s.), Actes du deuxième congrès international d'archéologie médiévale, Caen, 2-4 octobre 1987 (Caen, 1989) 77-83.

Fellows-Jensen, Gillian, Scandinavian Personal Names in Foreign Fields, Cahier des Annales de Normandie 23 (1990) 149-159.

Fellows-Jensen, Gillian, Vikings in the British Isles. The Place-Name Evidence, Acta Archaeologica 71 (2000) 135-146.

Foxhall, Lin, Gehrke, Hans-Joachim and Luraghi, Nino (eds.), Intentional History. Spinning Time in Ancient Greece (Stuttgart, 2010).

Foxhall, Lin and Luraghi, Nino, Introduction, in: Lin Foxhall, Hans-Joachim Gehrke and Nino Luraghi (eds.), Intentional History: Spinning Time in Ancient Greece (Stuttgart, 2010) 9-14.

Frank, Roberta, The Invention of the Viking Horned Helmet, in: Michael Dallapiazza (ed.), International Scandinavian and Medieval Studies in Memory of Gerd Wolfgang Weber (Trieste, 2000) 199-208.

Fuest, Veronika, Ethnologie in der Arena. Ein akteursanalytischer Blick in Umweltforschungsprojekte, Sociologus 56 (2006) 35-67.

Fujimura, Joan H. and Rajagopalan, Ramya, Different Differences: The Use of »Genetic Ancestry« versus Race in Biomedical Human Genetic Research, Social Studies of Science 41/1 (2011) 5-30. 
Gardner, Andrew, Paradox and Praxis in the Archaeology of Identity, in: Lindsay Amundsen-Meyer, Nicole Engel and Sean Pickering (eds.), Identity Crisis: Archaeological Perspectives on Social Identity, Proceedings of the 42nd Annual Chacmool Archaeology Conference, University of Calgary, Alberta (Calgary, 2011) 11-26.

Gautier, Alban, Du danger du mots transparents: dire le phénoméne anglo-scandinave dans quelques publication récentes en langue anglaise. Retrieved on 30 October 2016: $\mathrm{mmm}$. hypotheses.org/2900.

Gehrke, Hans-Joachim, Mythos, Geschichte, Politik - antik und modern, Saeculum 45 (1994) 239-264.

Gehrke, Hans-Joachim, Geschichte als Element antiker Kultur. Die Griechen und ihre Geschichte(n), Münchner Vorlesungen zu Antiken Welten 2 (Berlin, 2014).

Goodacre, Sara L., Helgason, Angnar, Nicholson, Jayne, Southam, Loz, Ferguson, Laura, Hickey, Eileen, Vega, Emilce, Stefánsson, Kári, Ward, Richard H. and Sykes, Bryan, Genetic Evidence for a Family-Based Scandinavian Settlement of Shetland and Orkney during the Viking Periods, Heredity 95/2 (2005) 129-135.

Gosden, Chris and Marshall, Yvonne, The Cultural Biography of Objects, World Archaeology 31/2 (1999) 169-178.

Gramsch, Alexander, Jenseits der »Zwei Kulturen«: Transfer und Transformation von Daten und Fragen zwischen Disziplinen. Kommentar zu Thomas Knopf und Petra Tillessen/ Doris Gutsmiedl-Schümann, in: Meier and Tillessen, Über die Grenzen und zwischen den Disziplinen, 209-218.

Gramsch, Alexander, Culture, Change, Identity: Approaches to the Interpretation of Cultural Change, Anthropologie 53/3 (2015) 341-349.

Griffiths, David and Harding, Stephen E., Interdisciplinary Approaches to the Scandinavian Heritage of North-West England, in: Harding et al., In Search of the Vikings, 1-32.

Griffiths, David, Harding, Stephen E. and Jobling, Mark A., Looking for Vikings in NorthWest England, British Archaeology 103 (2008) 18-25.

Gruner, Ivo, Gestatten meine Name ist Hase. Zu den Funktionen von Namen. Retrieved on 20 May 2016: juppes.org/upl/dateien/Gruner-2013_Funktionen-von-Namen.pdf.

Grupe, Gisela and Harbeck, Michaela, Isotopen- und DNA-Analysen aus Skelettfunden Erkenntnisgewinn oder Modeerscheinung?, in: Ondřej Chvojka, Miloslav Chytráček, Heinz Gruber, Jan Michálek, Ruth Sandner, Karl Schmotz, Karl and Stefan Traxler (eds.), Archäologische Arbeitsgemeinschaft Ostbayern /West- und Südböhmen/Oberösterreich - Archeologická pracovní skupina východní Bavorsko/západní a jižní Čechy/Horní Rakousko: 23. Treffen/setkání 19. bis 22. Juni 2013 in Kostenz, Fines Transire 23 (Rahden/Westf., 2014) 21-37.

Hahn, Hans P. and Weiss, Hadas (eds.), Mobility, Meaning and Transformation of Things: Shifting Contexts of Material Culture through Time and Space (Oxford, 2013).

Hall, Richard A., Scandinavian Settlement in England - the Archaeological Evidence, Acta Archaeologica 71 (2000) 147-157.

Haraway, Donna, When Species Meet, Posthumanities 3 (Minneapolis, 2008).

Haraway, Donna, When Species Meet: Staying with the Trouble, Environment and Planning D: Society and Space 28/1 (2010) 53-55.

Harding, Stephen E., Ingimund's Saga: Norwegian Wirral (second edition), (Birkenhead, 2006).

Harding, Stephen E., Jobling, Mark A. and King, Turi, Viking DNA: The Wirral and West Lancashire Project (Merseyside, 2010). 
Harding, Stephen E., Griffiths, David and Royles, Elizabeth (eds.), In Search of the Vikings: Interdisciplinary Approaches to the Scandinavian Heritage of North-West England (Boca Raton, 2015).

Hardtwig, Wolfgang and Schug, Alexander (eds.), History Sells! Angewandte Geschichte als Wissenschaft und Markt (Stuttgart, 2009).

Haubrichs, Wolfgang, Einleitung, in: Wolfgang Haubrichs (ed.), Namen, Zeitschrift für Literaturwissenschaft und Linguistik 67 (1987) 7-10.

Hedges, Robert E., A Comment on »The Potential Misuse of Genetic Analyses and the Social Construction of >Race and 'Ethnicity« « by Mirza and Dungworth, Oxford Journal of Archaeology 15 (1996) 107-108.

Hein, Till, Mythos und Legende: Die Allzweck-Barbaren, in: Die Wikinger - Krieger mit Kultur. Das Leben der Nordmänner, Spiegel Geschichte 6 (2010) 126-132.

Helgason, Agnar, Hickey, Eileen, Goodacre, Sara L., Bosnes, Vidar, Stefánsson, Kári, Ward, Richard H. and Sykes, Bryan, mtDNA and the Islands of the North Atlantic: Estimating the Proportions of Norse and Gaelic Ancestry, American Journal of Human Genetics 68/3 (2001) 723-737.

Helgason, Agnar, Sigurðardóttir, Sigrún, Nicholson, Jayne, Sykes, Bryan, Hill, Emmeline W., Bradley, Daniel G., Bosnes, Vidar, Gulcher, Jeffery R., Ward, Ryk and Stefánsson, Kári, Estimating Scandinavian and Gaelic Ancestry in the Male Settlers of Iceland, American Journal of Human Genetics 67/3 (2000) 697-717.

Hellberg, Staffan, Vikingatidens víkingar, Arkiv nordisk filologi 95 (1980) 25-88.

Helmbrecht, Michaela (ed.), Wikinger! Begleitbuch zur Erlebnisausstellung WIKINGER! im Ausstellungszentrum Lokschuppen Rosenheim, 11. März bis 04. Dezember 2016 (Hamburg, 2016).

Helmbrecht, Michaela, Die Wikinger und die politische Rechte, in: Helmbrecht (ed.), Wikinger!, 264-267.

Hillmore, Peter, The Viking Baby Invasion, The Mail on Sunday, [internet] 10 October 1999. Retrieved on 17 April 2016: www.highbeam.com/doc/1G1-109709864.html.

Hirschauer, Stefan, Un/Doing Differences. Die Kontingenz sozialer Zugehörigkeiten, Zeitschrift für Soziologie 43/3 (2014) 170-191.

Hobsbawm, Eric, Introduction: Inventing Traditions, in: Eric Hobsbawm and Terence Ranger (eds.), The Invention of Tradition (Cambridge, 1983) 1-14.

Hodder, Ian, Entangled: An Archaeology of the Relationships between Humans and Things (Malden/MA, 2012).

Hofmann, Daniela. What Have Genetics ever Done for Us? The Implications of aDNA Data for Interpreting Identity in Early Neolithic Central Europe, European Journal of Archaeo$\log y$ 18/3 (2015) 454-476.

Hofmann, Kerstin P., Anthropologie als umfassende Humanwissenschaft. Einige Bemerkungen aus archäologischer Sicht, Mitteilungen der Anthropologischen Gesellschaft in Wien 136/137 (2006/07) 283-300.

Hofmann, Kerstin P., Dinge als historische Quellen in Revision. Materialität, Spuren und Geschichten, in: Kerstin P. Hofmann, Thomas Meier, Doreen Mölders and Stefan Schreiber (eds.), Massendinghaltung in der Archäologie. Der material turn und die Ur- und Frühgeschichte (Leiden, 2016) 283-308. 
Hofmann, Kerstin P., Fundverbreitungen, archäologische Grenzen und Identitätsräume. Zum methodologischen Territorialismus der Bronzezeitforschung, in: Ute L. Dietz and Albrecht Jockenhövel (eds.), 50 Jahre Prähistorische Bronzefunde - Bilanz und Perspektiven: Beiträge zum internationalen Kolloquium am 24.-26. September 2014 in Mainz, Prähistorische Bronzefunde XX, 14 (Stuttgart, 2016) 207-226.

Jankuhn, Herbert and Wenskus, Reinhard (eds.), Geschichtswissenschaft und Archäologie. Untersuchungen zur Siedlungs-, Wirtschafts- und Kirchengeschichte, Vorträge und Forschungen 22 (Sigmaringen, 1979).

Jasanoff, Sheila, The Idiom of Co-Production, in: Sheila Jasanoff (ed.), States of Knowledge: The Co-Production of Science and Social Order (London, 2004) 1-12.

Jesch, Judith, Ships and Men in the Late Viking Age: The Vocabulary of Runic Inscriptions and Skaldic Verse (Woodbridge, 2001).

Jesch, Judith, The Viking Diaspora (London, 2015).

Jobling, Mark A., In the Name of the Father: Surnames and Genetics, Trends in Genetics 17/6 (2001) 353-357.

Johnston, Jenny, The Rise of the Baby Vikings: Why Single British Women Desperate for Children Are Turning to Sperm Donors in Denmark - Who'll Play no Part in Their Offspring's Lives, The Daily Mail, [internet] 20 January 2015. Retrieved on 28 April 2016: www.dailymail.co.uk/femail/article-2917432/The-rise-BABY-VIKINGS-single-British-womendesperate-children-turning-sperm-donors-Denmark-ll-play-no-offspring-s-lives.html.

Jones, Siân, The Archaeology of Ethnicity: Constructing Identities in the Past and Present (London, 1997).

Jordan, Stefan, Vetorecht der Quellen, Docupedia-Zeitgeschichte, 11.12.2010. Retrieved on 10 June 2016: docupedia.de/zg/Vetorecht_der_Quellen.

Kaiser, Elke and Schier, Wolfram (eds.), Mobilität und Wissenstransfer in diachroner und interdisziplinärer Perspektive, Topoi - Berlin Studies of the Ancient World 9 (Berlin, 2013).

Kershaw, Jane, Viking Identities: Scandinavian Jewellery in England (Oxford, 2013).

Kane, Jenny, DNA Tests Prove Scots Clan Are Viking not Irish, Deadline News, [internet] 15 January 2015. Retrieved on 28 April 2016: www.deadlinenews.co.uk/?p=67274.

Kant, Immanuel, Der Streit der Fakultäten [1798], in: Immanuel Kant, Schriften zur Anthropologie, Geschichtsphilosophie, Politik und Pädagogik, ed. Wilhelm Weischedel, Immanuel Kant Werkausgabe XI (Frankfurt a. M., 1977) 265-393.

King, Turi E. and Jobling, Mark A., Founders, Drift, and Infidelity: The Relationship between Y Chromosome Diversity and Patrilineal Surnames, Molecular Biology and Evolution 26/5 (2009) 1093-1102.

King, Turi E. and Jobling, Mark A., What's in a Name? Y Chromosomes, Surnames and the Genetic Genealogy Revolution, Trends in Genetics 25/8 (2009) 351-360.

Koch, Julia K., Geschlechterrollen zwischen den Zeilen. Möglichkeiten der Textanalyse archäologischer Fachliteratur, in: Ulrike Rambuscheck (ed.), Zwischen Diskursanalyse und Isotopenforschung. Methoden der archäologischen Geschlechterforschung, Bericht der 3. Sitzung der AG Geschlechterforschung auf der 78. Tagung des Nordwestdeutschen Verbandes für Altertumsforschung e.V. in Schleswig 2007, Frauen - Forschung - Archäologie 8 (Münster, 2009) 19-42.

Kopytoff, Igor, The Cultural Biography of Things. Commoditization as Process, in: Arjun Appadurai (ed.), The Social Life of Things: Commodities in Cultural Perspective (Cambridge, 1986) 64-91. 
Koselleck, Reinhart, Standortgebundenheit und Zeitlichkeit. Ein Beitrag zur historiographischen Erschließung der geschichtlichen Welt [1977], in: Reinhart Koselleck, Vergangene Zukunft. Zur Semantik geschichtlicher Zeiten (seventh edition), (Frankfurt a. M., 2010) 176207.

Kramer, Carol, Pots and People, in: Louis D. Levine and Theodore Cuyler Young (eds.), Mountains and Lowlands: Essays in the Archaeology of Greater Mesopotamia (Malibu, 1977) 91-112.

Krämer, Sybille, »Was eigentlich ist eine Karte?« Wie Karten Räume darstellen und warum Ptolemaios zur Gründerfigur wissenschaftlicher Kartografie wird, in: Ortwin Dally, Friederike Fless, Rudolf Haensch, Felix Pirson and Susanne Sievers (eds.), Politische Räume in vormodernen Gesellschaften. Gestaltung - Wahrnehmung - Funktion, Studien aus den Forschungsclustern des Deutschen Archäologischen Instituts 6 (Rahden/Westf., 2012) 47-53.

Kreuzer, Helmut (ed.), Literarische und naturwissenschaftliche Intelligenz. Dialog über die "zwei Kulturen“ (Stuttgart, 1969).

Kristiansen, Kristian, Genes versus Agents: A Discussion of the Widening Theoretical Gap in Archaeology, Archaeological Dialogues 11/2 (2004) 77-99.

Krüger, Jana, "Wikinger" im Mittelalter. Die Rezeption von víkingr m. und víking $f$. in der altnordischen Literatur, Ergänzungsbände zum Reallexikon der germanischen Altertumskunde 56 (Berlin, 2008).

Langthaler, Ernst, Orte in Beziehung. Mikrogeschichte nach dem Spatial Turn, Rural History Working Papers 16 (St. Pölten, 2013). Retrieved on 26 April 2016: www.ruralhistory.at/ de/publikationen/rhwp/RHWP16.pdf.

Lidén, Kerstin and Erikkson, Gunilla, Archaeology vs. Archaeological Science: Do We Have a Case?, Current Swedish Archaeology 21 (2013) 11-20.

Lee, Christina, Viking Age Women, in: Harding et al., In Search of the Vikings, 61-70.

Leslie, Stephen, Winney, Bruce, Hellenthal, Garrett, Davison, Dan, Boumertit, Abdelhamid, Day, Tammy, Hutnik, Katarzyna, Royrvik, Ellen C., Cunliffe, Barry, Lawson, Daniel J., Falush, Daniel, Freeman, Colin, Pirinen, Matti, Myers, Simon, Robinson, Mark, Donnelly, Peter and Bodmer, Walter, The Fine-Scale Genetic Structure of the British Population, Nature 519 (2015) 309-314.

Lowenthal, David, The Heritage Crusade and the Spoils of History (seventh edition), (Cambridge, 2009).

Lucas, Gavin, Understanding the Archaeological Record (Cambridge, 2012).

Marteau, Theresa and Richards, Martin (eds.), The Troubled Helix. Social and Psychological Implications of the New Human Genetics (Cambridge, 1996).

McEvoy, Brian, Brady, Claire, Moore, Laoise T. and Bradley, Daniel G., The Scale and Nature of Viking Settlement in Ireland from Y-Chromosome Admixture Analysis, European Journal of Human Genetics 14 (2006) 1288-1294.

M'charek, Amade, Schramm, Katharina and Skinner, David, Topologies of Race: Doing Territory, Population and Identity in Europe, Science, Technology and Human Values 39/4 (2014) 468-487.

Meier, Thomas and Tillessen, Petra (eds.), Über die Grenzen und zwischen den Disziplinen. Fächerübergreifende Zusammenarbeit im Forschungsfeld historischer Mensch-Umwelt-Beziehungen (Budapest, 2011).

Meier, Thomas and Tillessen, Petra, Von Schlachten, Hoffnungen und Ängsten. Einführende Gedanken zur Interdisziplinarität in der Historischen Umweltforschung, in: Meier and Tillessen, Über die Grenzen und zwischen den Disziplinen, 19-44. 
Menhorn, Christian, Skinheads. Portrait einer Subkultur, Extremismus und Demokratie 3 (Baden-Baden, 2001).

Meskell, Lynn, Archaeologies of Identity, in: Ian Hodder (ed.), Archaeological Theory Today (Cambridge, 2001) 187-213.

Mirza, M. N. and Dungworth, David B., The Potential Misuse of Genetic Analyses and the Social Construction of >Race and `Ethnicity`, Oxford Journal of Archaeology 14/3 (1995) 345-354.

Mittelstraß, Jürgen, Die Häuser des Wissens. Wissenschaftstheoretische Studien (Frankfurt a. M., 1998).

Morning, Ann, And You Thought We Had Moved beyond All That: Biological Race Returns to the Social Sciences, Ethnic and Racial Studies 37/10 (2014) 1676-1685.

Müller, Johannes, Kossinna, Childe and aDNA: Comments on the Construction of Identities, Current Swedish Archaeology 21 (2013) 35-38.

Müller-Wille, Michael, The Political Misuse of Scandinavian Prehistory in the Years 19331945, in: Else Roesdahl and Preben Meulengracht Sørensen (eds.), The Waking of Angantyr: The Scandinavian Past in European Culture. Den Nordiske Fortid i Europæisk Kultur, Acta Jutlandica 71/1, Humanities Series 70 (Aarhus, 1996) 156-175.

Nash, Catherine, Irish DNA: Making Connections and Making Distinctions in Y-Chromosome Surname Studies, in: Katharina Schramm, David Skinner and Richard Rottenburg (eds.), Identity Politics and the New Genetics: Re/Creating Categories of Difference and Belonging, Studies of Biosocial Society 6 (New York, 2012) 141-166.

Nash, Catherine, Genome Geographies. Mapping National Ancestry and Diversity in Human Population Genetics, Transactions of the Institute of British Geographers 38/2 (2013) 193206.

Nature Publishing Group, Source Material: Geneticists and Historians Need to Work Together on Using DNA to Explore the Past, Nature (26 May 2006) 437-438. Retrieved on 15 June 2016: http://www.nature.com/news/source-material-1.19962.

Nelson, Janet, England and the Continent in the Ninth Century II: The Vikings and Others, Transactions of the Royal Historical Society 13 (2003) 1-28.

Nießer, Jacqueline and Tomann, Juliane (eds.), Angewandte Geschichte. Neue Perspektiven auf Geschichte in der Öffentlichkeit (Paderborn, 2014).

Novembre, John, Johnson, Toby, Bryc, Katarzyna, Kutalik, Zoltán, Boyko, Adam R., Auton, Adam, Indap, Amit, King, Karen S., Bergmann, Sven, Nelson, Matthew R., Stephens, Matthew and Bustamante, Carlos D., Genes Mirror Geography within Europe, Nature 456/6 (2008) 98-101.

Oppenheimer, Stephen, The Origins of the British: The New Prehistory of Britain from Ice-Age Hunter Gatherers to Vikings as Revealed by DNA Analysis (London, 2007).

Patzel, Katja, »Alle Erinnerung ist Gegenwart«. Zur Selbstverortung des Individuums im Prozeß der Modernisierung, in: Clemens Wischermann (ed.), Die Legitimität der Erinnerung und die Geschichtswissenschaft, Studien zur Geschichte des Alltags 15 (Stuttgart, 1996) 189-213.

Pluciennik, Mark, Genetics, Archaeology and the Wider World, Antiquity 70/267 (1996) 1314.

Pluciennik, Mark, Clash of Cultures? Archaeology and Genetics, Documenta Praehistorica 33 (2006) 39-49.

Pohl, Walter, Comparing Communities - The Limits of Typology, History and Anthropology 26/1 (2015) 18-35. 
Raabe, Jan, and Schlegelmilch, Dana, Die rezente Rechte und das Germanentum, in: Focke-Museum (ed.), Graben für Germanien. Archäologie unterm Hakenkreuz. Ausstellung Focke-Museum, Bremer Landesmuseum für Kunst und Kulturgeschichte, 10.3.-8.9. 2013 (Stuttgart, 2013) 172-178.

Rabinow, Paul, Artificiality and Enlightenment: From Sociobiology to Biosociality, in: Jonathan Crary and Sanford Kwinter (eds.), Incorporations: Zone 6 (New York, 1992) 234-252.

Redmonds, George, King, Turi and Hey, David, Surnames, DNA, and Family History (Oxford, 2011).

Reinalter, Helmut (ed.), Natur- und Geisteswissenschaften. Zwei Kulturen?, Arbeitskreis Wissenschaft und Verantwortlichkeit 4 (Innsbruck, 1999).

Renfrew, Colin, Before Civilization: The Radiocarbon Revolution and Prehistoric Europe (New York, 1973).

Renger, Almut-Barbara and Toral-Niehoff, Isabel (eds.), Genealogie und Migrationsmythen im antiken Mittelmeerraum und auf der Arabischen Halbinsel, Topoi: Berlin Studies of the Ancient World 29 (Berlin, 2014).

Richards, Julian D., Identifying Anglo-Scandinavian Settlements, in: Dawn M. Hadley and Julian D. Richards (eds.), Cultures in Contact: Scandinavian Settlement in England in the Ninth and Tenth Centuries (Turnhout, 2000) 295-309.

Richards, Julian D., The Vikings: A Very Short Introduction (Oxford, 2005).

Richards, Julian D., Viking Settlement in England, in: Brink and Price, Viking World, 368-374.

Röder, Brigitte, Jäger sind anders - Sammlerinnen auch. Zur Deutungsmacht des bürgerlichen Geschlechter- und Familienmodells in der Prähistorischen Archäologie, in: Tobias L. Kienlin (ed.), Fremdheit - Perspektiven aufdas Andere, Cologne Contibutions to Archaeology and Cultural Studies 1, Universitätsforschungen zur prähistorischen Archäologie 264 (Bonn, 2015) 237-253.

Roesdahl, Elke and Wilson, David M. (eds.), From Viking to Crusader: Scandinavians and Europe, 800-1200 (New York, 1992).

Samida, Stefanie and Eggert, Manfred K. H., Über Interdisziplinarität. Betrachtungen zur Kooperation von Natur- und Kulturwissenschaften in der Archäologie, Hephaistos 29 (2012) 9-24.

Samida, Stefanie and Eggert, Manfred K. H., Archäologie als Naturwissenschaft? Eine Streitschrift, Pamphletliteratur 5 (Berlin, 2013)

Saupe, Achim and Wiedemann, Felix, Narration und Narratologie. Erzähltheorien in der Geschichtswissenschaft, Docupedia-Zeitgeschichte, 28.01.2015. Retrieved on 22 April 2016: docupedia.de/zg/Narration.

Sawyer, Peter H., Kings and Vikings: Scandinavia and Europe, A.D. 700-110o (second edition), (London, 2003).

Scarre, Christopher and Scarre, Geoffrey (eds.), The Ethics of Archaeology: Philosophical Perspectives on Archaeological Practice (Cambridge, 2006).

Schmidt, Jan C., Towards a Philosophy of Interdisciplinarity, Poiesis and Praxis 5/1 (2008) 53-69.

Schramm, Katharina, Neue Technologien - alte Kategorien? Die Problematisierung von Rasse an der Schnittstelle von Wissenschaft und Politik, Zeitschrift für Ethnologie 139 (2014) 233-252. 
Schreiber, Stefan, Vergangenheit als personaler Wissensraum. Oder: Wie bastle ich mir meine eigenen Vergangenheiten?, in: Kerstin P. Hofmann and Stefan Schreiber (eds.), Raumwissen und Wissensräume. Beiträge des interdisziplinären Theorie-Workshops für Nachwuchswissenschaftler_innen, eTopoi. Journal for Ancient Studies, Special Volume 5 (Berlin, 2015) 195-212. Retrieved on 21 November 2016: journal.topoi.org/index.php/etopoi/article/ view/217.

Scully, Marc, King, Turi and Brown, Steven D., Remediating Viking Origins: Genetic Code as Archival Memory of the Remote Past, Sociology 47/5 (2013) 921-938.

Serres, Michel, Aufklärungen. Fünf Gespräche mit Bruno Latour, Internationaler Merve-Diskurs 308 (Berlin, 2008).

Simpson, Bob, Imagined Genetic Communities. Ethnicity and Essentialism in the Twenty-First Century, Anthropology Today 16/3 (2000) 3-6.

Sjögren, Karl-Goran, Price, T. Douglas and Kristiansen, Kristian, Diet and Mobility in the Corded Ware of Central Europe, PLoS One 11/5 (2016). Retrieved on 21. November 2016: journals.plos.org/plosone/article?id=10.1371/journal.pone.0155083.

Smith, Adam T., The End of the Essential Archaeological Subject, Archaeological Dialogues 11/1 (2004) 1-20.

Smyth, Alfred P., Scandinavian York and Dublin: The History and Archaeology of Two Related Viking Kingdoms (Dublin, 1975).

Snow, Charles Percy, The Two Cultures (London, 1959).

Sommer, Marianne, Angewandte Geschichte auf genetischer Grundlage, Nach Feierabend. Zürcher Jahrbuch für Wissensgeschichte 4 (2008) 129-148.

Sommer, Marianne, History in the Gene: Negotiations between Molecular and Organismal Anthropology, Journal of the History of Biology 41 (2008) 473-528.

Sommer, Marianne, "Wer sind Sie wirklich?« - Identität und Geschichte in der >Gensequenz', L' Homme 21/2 (2010) 51-70.

Sommer, Marianne, 'It's a Living History, Told by the Real Survivors of the Times - DNAr. Anthropological Genetics in the Tradition of Biology as Applied History, in: Keith Wailoo, Alondra Nelson and Cathrine Lee (eds.), Genetics and the Unsettled Past. The Collision of DNA, Race, and History (New Brunswick, 2012) 225-246.

Sommer, Marianne, Population-Genetic Trees, Maps, and Narratives of the Great Human Diasporas, History of the Human Sciences (2015) 1-38.

Sonderegger, Stefan. Die Bedeutsamkeit der Namen, Zeitschrift für Literaturwissenschaft und Linguistik 17/67 (1987) 11-23.

Sørensen, Marie L., Gender, Material Culture, and Identity in the Viking Diaspora, Viking and Medieval Scandinavia 5 (2009) 253-269.

Spinozzi, Paola and Hurwitz, Brian (eds.), Discourses and Narrations in the Biosciences, Interfacing Science, Literature, and the Humanities 8 (Göttingen, 2011).

Strohmaier, Alexandra (ed.), Kultur - Wissen - Narration. Perspektiven transdisziplinärer Erzählforschung für die Kulturwissenschaften (Bielefeld, 2013).

Sykes, Bryan, The Seven Daughters of Eve (London, 2001).

Sykes, Bryan, Blood of the Isles: Exploring the Genetic Roots of Our Tribal History (London, 2006).

Sykes, Bryan and Irven, Catherine, Surnames and the Y Chromosome, American Journal of Human Genetics 66/4 (2000) 1417-1419.

Thomas, Julian, Gene-Flows and Social Processes: The Potential of Genetics and Archaeology, Documenta Praehistorica 33 (2006) 51-59. 
Tomann, Juliane, Nießer, Jacqueline, Littke, Anna, Ackermann, Jakob and Ackermann, Felix, Diskussion Angewandte Geschichte: Ein neuer Ansatz?, Docupedia-Zeitgeschichte, 15.02.2011. Retrieved on 22 April 2016: docupedia.de/zg/Diskussion_Angewandte_Geschichte.

Tschofen, Bernhard, Antreten, ablehnen, verwalten? Was der Heritage-Boom den Kulturwissenschaften aufträgt, in: Dorothee Hemme, Markus Tauschek and Regina Bendix (eds.), Prädikat "Heritage". Wertschöpfungen aus kulturellen Ressourcen, Studien zur Kulturanthropologie/Europäischen Ethnologie 1 (Berlin, 2007) 19-32.

Ucko, Peter J., Introduction. Archaeological Interpretation in a World Context, in: Peter J. Ucko, (ed.), Theory in Archaeology: A World Perspective (London, 1995) 1-28.

Veit, Ulrich, `Mission Impossible!^ Comment on Kristiansen, Genes versus Agents. A Discussion of the Widening Theoretical Gap in Archaeology, Archaeological Dialogues 11/2 (2004) 99-103.

Veit, Ulrich, Der Archäologe und das Fremde. Zur Erkenntnisstruktur der Ur- und Frühgeschichtswissenschaft, Mitteilungen der Anthropologischen Gesellschaft in Wien 128 (1998) 125-137.

Voss, Barbara L., What's New? Rethinking Ethnogenesis in the Archaeology of Colonialism, American Antiquity 80/4 (2015) 655-670.

Wallace, Patrick F., The Archaeological Identity of the Hiberno-Norse Town, The Journal of the Royal Society of Antiquaries of Ireland 22 (1992) 35-66.

Wawn, Andrew, The Vikings and the Victorians: Inventing the Old North in Nineteenth-Century Britain (Cambridge, 2000).

Wenskus, Reinhard, Randbemerkungen zum Verhältnis von Historie und Archäologie, insbesondere mittelalterlicher Geschichte und Mittelalterarchäologie, in: Jankuhn and Wenskus, Geschichtswissenschaft und Archäologie, 637-657.

Werle, Raymund, Pfadabhängigkeit, in: Arthur Benz, Susanne Lütz, Uwe Schimank and Georg Simonis (eds.), Handbuch Governance. Theoretische Grundlagen und empirische Anwendungsfelder (Wiesbaden, 2007) 119-131.

White, Hayden V., Auch Klio dichtet, oder: Die Fiktion des Faktischen. Studien zur Tropologie des historischen Diskurses, Sprache und Geschichte 10 (Stuttgart, 1986).

Wiedemann, Felix, Völkerwellen und Kulturbringer. Herkunfts- und Wanderungsnarrative in historisch-archäologischen Interpretationen des Vorderen Orients um 1900, Ethnographisch-Archäologische Zeitschrift 51 (2010) 105-128.

Wiedemann, Felix, Stones and Stories: On the Use of Narratological Approaches for Writing the History of Archaeology, in: Gisela Eberhardt and Fabian Link (eds.), Historiographical Approaches to Past Archaeological Research, Topoi: Berlin Studies of the Ancient World 32 (Berlin, 2015) 95-114.

Wiedemann, Felix, Hofmann, Kerstin P. and Gehrke, Hans-Joachim, Wanderungsnarrative. Zur Verknüpfung von Identitäten und Raum in altertumswissenschaftlichen Migrationserzählungen, in: Felix Wiedemann, Kerstin P. Hofmann and Hans-Joachim Gehrke (eds.), Vom Wandern der Völker. Migrationserzählungen in den Altertumswissenschaften, Topoi: Berlin Studies of the Ancient World 41 (Berlin) forthcoming.

Wiggins, David, Sameness and Substance Renewed (Cambridge, 2001).

Williams, Gareth, Pentz, Peter and Wemhoff, Matthias (eds.), Vikings: Life and Legend (London, 2014). 
Wilson, James F., Weiss, Deborah A., Richards, Martin, Thomas, Mark G., Bradman, Nell and Goldstein, David B., Genetic Evidence for Different Male and Female Roles during Cultural Transitions in the British Isles, Proceedings of the National Academy of Sciences of the United States of America 98/9 (2001) 5078-5083.

Winney, Bruce, Boumertit, Abdelhamid, Day, Tammy, Davison, Dan, Echeta, Chikodi, Evseeva, Irina, Hutnik, Katarzyna, Leslie, Stephen, Nicodemus, Kristin, Royrvik, Ellen C., Tonks, Susan, Yang, Xiaofeng, Cheshire, James, Longley, Paul, Mateos, Pablo, Groom, Alexandra, Relton, Caroline, Bishop, D. Tim, Black, Kathryn, Northwood, Emma, Parkinson, Louise, Frayling, Timothy M., Steele, Anna, Sampson, Julian R., King, Turi, Dixon, Ron, Middleton, Derek, Jennings, Barbara, Bowden, Rory, Donnelly, Peter and Bodmer, Walter, People of the British Isles: Preliminary Analysis of Genotypes and Surnames in a UK-Control Population, European Journal of Human Genetics 20/2 (2012) 203-210.

Wiwjorra, Ingo, Ethnische Anthropologie. Zwischen scientistischer Innovation und völkischer Tradition, in: Uwe Puschner and G. Ulrich Großmann (eds.), Völkisch und national. Zur neuen Aktualität alter Denkmuster im 21. Jahrhundert, Wissenschaftliche Beibände zum Anzeiger des Germanischen Nationalmuseums 5 (Darmstadt, 2009) 128-144.

Yanagisako, Sylvia Junko and Delaney, Carol Lowery, Naturalizing Power, in: Sylvia Junko Yanagisako and Carol Lowery Delaney (eds.), Naturalizing Power: Essays in Feminist Cultural Analysis (New York, 1995) 1-22.

Zabeeh, Farhang, What is in a Name? An Inquiry into the Semantics and Pragmatics of Proper Names (The Hague, 1968).

Zettel, Horst, Das Bild der Normannen und der Normanneneinfälle in westfränkischen, ostfränkischen und angelsächsischen Quellen des 8. bis 11. Jahrhunderts (München, 1977).

Zuckerkandl, Emile and Pauling, Linus B., Molecular Disease, Evolution, and Genetic Heterogeneity, in: Michael Kasha and Bernard Pullman (eds.), Horizons in Biochemistry (New York, 1962) 189-225. 